\title{
Ghaba Salt Basin Province and Fahud Salt Basin Province, Oman -- Geological Overview and Total Petroleum Systems
}

By RICHARD M. POLLASTRO

U.S. GEOLOGICAL SURVEY OPEN-FILE REPORT 99-50-D

This report is preliminary and has not been reviewed for conformity with the U.S. Geological Survey editorial standards and stratigraphic nomenclature. A ny use of trade names is for descriptive purposes only and does not imply endorsement by the U S. government.

U.S. Department of the Interior 
Petroleum Systems and Geologic Overview of Ghaba and Fahud Salt Basin Provinces -- Pollastro

\section{U.S. Geological Survey}

1999 


\title{
Ghaba Salt Basin Province and Fahud Salt Basin Province, Oman -- Geological Overview and Total Petroleum Systems
}

\author{
By Richard M. Pollastro ${ }^{1}$
}

\section{FORWARD}

This report is a product of the World Energy Project of the U.S. Geological Survey, in which the world has been divided into 8 regions and 937 geologic provinces for purposes of assessment of global oil and gas resources (Klett and others, 1997). These provinces have been ranked according to the discovered petroleum volumes within each; 76 "priority" provinces (exclusive of the U.S. and chosen for their high ranking) and 26 "boutique" provinces (exclusive of the U.S. and chosen for various reasons) were selected for appraisal of oil and gas resources. The petroleum geology of these nonU.S. priority and boutique provinces is described in this series of reports. Assessment results will be released in a later report, if such results are not reported herein. More specific digital compilations of the geology and province boundaries of the Arabian Peninsula are also available on CD-ROM (Pollastro and others, 1998).

The Total Petroleum System constitutes the basic geologic unit to be assessed for undiscovered oil and gas resources. A Total Petroleum System includes the essential elements and processes, as well as all genetically related hydrocarbons, that occur in petroleum shows, seeps, and accumulations (discovered and undiscovered) whose provenance is a pod or closely related pods of mature source rock (modified from Magoon and Dow, 1994). The minimum petroleum system is that portion of the Total Petroleum System for which the presence of essential elements and processes has been proved.

1 U.S. Geological Survey, Denver, CO, 80225
An assessment unit is a mappable volume of rock within the Total Petroleum System that encompasses petroleum fields (discovered and undiscovered) which share similar gross geologic traits and socio-economic factors. The fields in an assessment unit should constitute a population that is sufficiently homogeneous in terms of geology, exploration strategy, and risk so that the chosen methodology of resource assessment is applicable. A Total Petroleum System might equate to a single assessment unit. If necessary, a Total Petroleum System can be subdivided into two or more assessment units in order that each assessment unit is sufficiently homogeneous. Each assessment unit can incorporate several exploration plays based on different reservoir formations, trap types, exploration strategies, and discovery histories. Assessment units are considered established if they contain more than 13 fields, frontier if they contain 1-13 fields, and hypothetical if they contain no fields.

A numeric code identifies each region, province, Total Petroleum System, and assessment unit; these codes are uniform throughout the project and will identify the same item in any of the publications. The code is as follows:

Region, single digit
$\begin{aligned} & \text { Example } \\ & \text { Province, three digits to the right of region } \\ & \text { code }\end{aligned}$
$\begin{array}{ll}\text { Total Petroleum System, three digits to the } \\ \text { right of province code } & 3162050 \\ \text { Assessment unit, one digit to the right of } \\ \text { petroleum system code } & 31620504\end{array}$

Region, single digit 
The codes for the regions and provinces were established, listed, and mapped in Klett and others, 1997.

The purpose of describing the Total Petroleum Systems of this area is to aid in assessing the quantities of oil, gas, and natural gas liquids that have the potential to be added to reserves within the next 30 years. These volumes either reside in undiscovered fields whose sizes exceed the stated minimum-fieldsize cutoff value for the assessment unit or occur as reserve growth of fields already discovered.

"Reserves" quoted in this report are from Petroconsultants, Inc., 1996 Petroleum Exploration and Production database and other area reports from Petroconsultants, Inc., unless otherwise stated.

Figure(s) in this report that show boundaries of the Total Petroleum System(s), assessment units, and pods of active source rock were originally compiled using geographic information system (GIS) software and then later drafted into the present illustrations. Political boundaries and cartographic representations were taken, with permission, from ESRI's ArcWorld 1:3 million digital coverage, have no political significance, and are displayed for general reference only. Oil and gas field centerpoints, shown on drafted figure(s) are reproduced, with permission, from Petroconsultants, Inc., 1996 Worldwide Oil and Gas Field database.

Also included as figures are events charts that show the time of deposition of essential rock units; the time processes, such as trap formation, necessary to the accumulation of hydrocarbons took place; the critical moment in the petroleum system; and the preservation time, if any. The format is that proposed by Magoon and Dow (1994).

\section{REFERENCES}

Environmental Systems Research Institute Inc., 1992, ArcWorld 1:3M digital database: Environmental Systems Research Institute, Inc. (ESRI), available from ESRI, Redlands, CA, scale: 1:3,000,000.

Klett, T.R., Ahlbrandt, T.A., Schmoker, J.W., and Dolton, G.L., 1997, Ranking of the world's oil and gas provinces by known petroleum volumes: U.S. Geological Survey Open-File Report 97-463, one CD-ROM.

Magoon, L. B., and Dow, W. G., 1994, The petroleum system, in Magoon, L. B., and Dow, W. G., eds., The Petroleum System from Source to Trap: American Association of Petroleum Geologists Memoir 60, p. 3-24.

Petroconsultants International Data Corporation, 1996, Petroconsultants Wordwide Oil and Gas Field Database 1996: Geneva, Switzerland, Petroconsultants International Data. Digital database available from Petroconsultants International Data Corporation, P.O. Box 740619, 6600 Sands Point Drive, Houston TX 77274-0619, USA or Petroconsultants, Inc.,P.O. Box 152, 24 Chemin de la Mairie, 1258 Perly, Geneva.

Petroconsultants, Inc., 1996, Petroleum Exploration and Production Database: Petroconsultants, Inc., P.O. Box 740619, 6600 Sands Point Drive, Houston TX 772740619, USA or Petroconsultants, Inc.,P.O. Box 152, 24 Chemin de la Mairie, 1258 Perly, Geneva, Switzerland.

Pollastro, R.M., Karshbaum, A.S., and Viger, R.J., 1998, Map showing geology, oil and gas fields, and geologic provinces of the Arabian Peninsula: U.S. Geological Survey Open-File Report 97-470B, one CD-ROM.

\section{ACKNOWLEDGMENTS}

This manusript has benefited considerably from the scientific contributions and assistance from several individuals. In particular, I would especially like to thank Joachim Amthor, Jos Terken, Graham Tiley, and Mike Naylor of Petroleum Development Oman, and Wallace Pierce of Amoco Production for contributing information and data, and participating in discussions on the petroleum systems of Oman. I would also like to thank Tim Klett, Tom Ahlbrandt, Chris Schenk, and Jim Schmoker for their suggestions and discussions during the preparation of this report. Moreso, the manuscript has improved greatly from critical reviews by Chris Schenk and Tom Ahlbrandt. Thanks also to Felix Persits for his assistance in preparing the digital maps. 


\section{Abstract}

Three Total Petroleum Systems each consisting of one assessment unit have been identified in the Ghaba and Fahud Salt Basin Provinces of north-central Oman. One Total Petroleum System and corresponding assessment unit, the North Oman Huqf/' $Q$ '-Haushi(!) Total Petroleum System (201401) and Ghaba-Makarem Combined Structural Assessment Unit (20140101), were identified for the Ghaba Salt Basin Province (2014). In the Fahud Salt Basin Province, however, two overlapping Total Petroleum Systems (TPS) were recognized: 1) the North Oman Huqf -Shu'aiba(!) TPS (201601); Fahud-Huqf Combined Structural Assessment Unit (20160101), and 2) the Middle Cretaceous Natih(!) TPS (201602); Natih-Fiqa Structural/Stratigraphic Assessment Unit (20160201). The boundary for each Total Petroleum System also defines the boundary of the corresponding assessment unit and includes all trap styles and hydrocarbon producing reservoirs within the petroleum system.

In both the Ghaba and Fahud Salt Basin Provinces, hydrocarbons were generated from several deeply-buried source rocks within the Infracambrian Huqf Supergroup. One general 'North Oman Huqf' type oil is dominant in the Fahud Salt Basin. Oils in the Ghaba Salt Basin are linked to at least two distinct Huqf sourcerock units based on oil geochemistry: a general North Oman Huqf-type oil source and a more dominant 'questionable unidentified-source' or

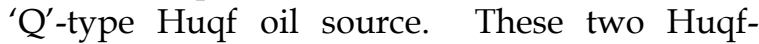
sourced oils are commonly found as admixtures in reservoirs throughout north-central Oman.

Hydrocarbons generated from Huqf sources are produced from a variety of reservoir types and ages ranging from Precambrian to Cretaceous in both the Ghaba and Fahud Salt Basin Provinces. Clastic reservoirs of the Gharif and Al Khlata Formations, Haushi Group (M. Carboniferous to L. Permian), dominate oil production in the Ghaba Salt Basin Province and form the basis for the Huqf/' $Q$ ' -- Haushi(!) TPS. In contrast, the Lower Cretaceous Shu'aiba and Middle Cretaceous Natih limestones account for most of the production in the Fahud Salt Basin with about 50 percent of the basin's production from porous, fractured Shu'aiba limestones in Yibal field, thus the name North Oman Huqf -Shu'aiba(!) TPS. Deep gas is produced mainly from Middle Cambrian to Lower Ordovician clastic reservoirs of the Haima Supergroup. Traps in nearly all hydrocarbon accumulations of these petroleum systems are mainly structural and were formed by one or more mechanisms. These trap-forming mechanisms were mainly periodic halokinesis of the thick Cambrian Ara Salt and consequent folding and faulting from basin loading, rifting, or other major tectonic events, particularly those events forming the Oman Mountains and associated foreland-basin system during the Late Cretaceous and Late Tertiary.

Many of the future new-field targets will likely be low-relief, subtle structures, as many of the large structures have been drilled. Oman's recent interest and commitments to liquid natural gas export make deep gas a primary objective in the two North Oman Huqf petroleum systems. New-field exploration of deep gas and exploring deeper targets for gas in existing fields will likely identify a significant gas resource in the next thirty years. Moreover, salt-diapir flank traps in these two North Oman Huqf petroleum systems and salt basin provinces have gone essentially untested and will likely be targeted in the near-future.

The Middle Cretaceous Natih(!) TPS is a small efficient system of the Fahud Salt Basin. Natih source rocks are only mature in the Late Cretaceous/Tertiary foredeep and production is primarily from Natih reservoirs; minor production from the Shu'aiba limestone is documented along fault-dip structures. Most traps are structural and are related to development of the foreland basin and formation of the Oman Mountains. Future targets of the Natih TPS will be less obvious than those of Fahud and Natih fields and likely include smaller structural closures along the northern flank of the foreland bulge and traps above salt domes with late Tertiary movement. Frontier exploration is predicted to be mainly in stratigraphic traps within Natih buildups and in unproven turbidite and other marine clastics of the Fiqa Formation. 


\section{INTRODUCTION}

The U.S. Geological Survey, World Energy Project, has divided the world into 8 regions and 937 geologic provinces for purposes of assessment of global oil and gas resources. These provinces have been ranked according to the discovered petroleum volumes within each; 76 "priority" provinces (high-ranking and exclusive of the U.S.) and 26 "boutique" provinces (chosen and exclusive of the U.S.) were designated for appraisal of oil and gas resources (Klett and others, 1997). The Ghaba and Fahud Salt Basin Provinces of Oman (USGS World Energy Project provinces 2014 and 2016, respectively; see Pollastro and others, 1998) are two of the 76 "priority" provinces; the Ghaba Salt Basin Province ranked number 69 and the Fahud Salt Basin Province ranked number 59. Total recoverable reserves are estimated at 5.0 billion barrels of oil equivalent (BBOE) for the Ghaba Salt Basin Province and 6.3 BBOE for the Fahud Salt Basin Province (Klett and others, 1997). The location and boundaries of these provinces are shown in figure 1. The largest field in the Ghaba Salt Basin is Saih Rawl (fig. 2). Yibal field (fig. 2) is the largest field of the Fahud Salt Basin, and in Oman in general; early conservative estimates of in place reserves at Yibal have been reported at about 3.0 billion barrels of stocktank oil (Litsey and others, 1983). Moreover, Yibal accounts for about 25 percent of Oman's developed reserves, currently producing about 217,000 barrels of oil per day (BOPD) (Knott, 1998).

The Total Petroleum System concept is the basis for this assessment. A Total Petroleum System includes the essential elements and processes, as well as genetically related hydrocarbons that occur in petroleum shows, seeps, and accumulations (discovered and undiscovered), whose provenance is a pod or pods of mature source rock (concept modified from Magoon and Dow, 1994). The minimum petroleum system is that portion of the system for which the presence of essential elements and processes has been proved. The assessment unit is a mapable volume of rock within the Total Petroleum System, sufficiently homogeneous in terms of geology, exploration strategy, and risk characteristics to constitute a single population with respect to criteria used for the chosen methodology of resource assessment. The assessment unit, however, may be limited to the data and information available for assessment of the resource(s), thus limiting the degree of "homogeneity". Assessment units are considered established if they contain more than 13 fields, frontier if they contain 1-13 fields, and hypothetical if they contain no fields.

A unique eight-digit numeric code identifies each assessment unit with respect to the region, province, and Total Petroleum System. The first digit is the region number, the next three digits the province number, the next two digits the Total Petroleum System number, and the final two digits are the assessment number. The codes for the regions and provinces were established, listed in Klett and others (1997); provinces for the Arabian Penisula are listed and shown in greater detail in Pollastro and others (1998).

Oil and gas production in Oman has grown considerably in the past 36 years to a present level of about 900,000 BOPD (U.S. Energy Information Administration, 1998; Petroleum Economist, 1998; Knott, 1998). Although conventional plays have been mostly identified with successful production, Oman has added at least one $\mathrm{BBOE}$ to their reserves in the past three years. In particular, non-associated deep-gas production and reserve calculations from frontier plays have exceeded industry expectations. These reasons further justify the need for a better understanding of the petroleum systems of Oman and a focused and specialized assessment of oil and gas resources in the Ghaba and Fahud Salt Basin Provinces. The Ghaba and Fahud Salt Basin Provinces are treated together here since they are geologically comparable and also both entirely within the country of Oman.

\section{PROVINCE GEOLOGY AND PETROLEUM OCCURRENCE}

\section{Province Boundaries}

The Ghaba and Fahud Salt Basin Provinces (fig. 1) are primarily defined by their bounding structures and, for the most part, the geographic 
extent of the deep, Cambrian Ara Salt. The Ghaba Salt Basin Province (2014) is bounded on the east-southeast by the Huqf-Haushi Uplift and outcrops, to the north by the Oman Mountains, to the northwest by the Central Oman Platform, and to the south and southwest by the Central Oman High and GhudunKhasfah High, respectively (fig. 2). The Fahud Salt Basin Province (2016) is bounded on the northeast by the Oman Mountains, to the west by the Lekhwair-Safah Arch, and to the south by the Central Oman Platform. The MakaremMabrouk High, a northern extension of the Central Oman Platform (fig. 2), separates the two basins (Gorin and others, 1982; Boote and others, 1990; Robertson and others, 1990; Mattes and Conway-Morris, 1990; Loosveld and others, 1996). Both the Ghaba and Fahud Salt Basin Provinces lie entirely within the country of Oman (see Pollastro and others, 1998).

\section{Structural Setting}

Oman is located on the southeastern margin of the Arabian plate and is close to the boundaries of the Iranian, Indian, and African plates. Consequently, plate movements have resulted in complex structural, sedimentation, and burial histories. Oman is tectonically bounded on the south by the Gulf of Aden spreading zone, to the east by the Masirah Transform Fault and the Owen Fracture Zone Trough, and to the north by the complex ZagrosMakran convergent plate margin, compression along which produced the Oman Mountains (Loosveld and others, 1996). Precambrian metamorphic and igneous base- ment rocks are known from a limited number of wells and from exposures of bedrock along the Huqf-Haushi Uplift on Oman's eastern margin (figs. 1 and 2).

The Ghaba Salt Basin, South Oman Salt Basin (2011; figs. 1, 2), and to a lesser extent, the Fahud Salt Basin are part of a series of subsiding rift basins stretching from India and Pakistan across the Arabian Shield to central Iran that formed during the Infracambrian and lower Cambrian (about 600 to $540 \mathrm{Ma}$ ). (Gorin and others, 1982; Husseini and Husseini, 1990; Mattes and Conway-Morris, 1990). These rift basins were formed by extension from left- lateral, strike-slip (rifting and wrenching) movement of the Najd transform fault system which ultimately dislocated the Arabian plate some $300 \mathrm{~km}$ to the east (Schmidt and others, 1979). Generalized cross sections across the Ghaba and Fahud Salt Basins are shown in figures 3 and 4.

\section{Stratigraphy}

The sedimentary section in the hydrocarbonproducing provinces of Oman is made up of rocks ranging from Proterozoic to Recent (Hughes-Clarke, 1988). Clastic rocks comprise most of the lower Paleozoic part of the section, whereas, the Permian through Tertiary (fig. 5) part of the section are predominantly carbonate rocks and reflect climatic variations due to Oman's changing paleolatitude through geologic time (Beydoun, 1991). For example, carbonate platforms were dominant during periods when Oman was above $30^{\circ}$ south latitude. Earliest sediments of Oman are a clastic-carbonateevaporite sequence of the Huqf Supergroup (Droste, 1997) best known from outcrops of the Huqf-Haushi swell (figs. 1 and 2) and in the subsurface in southeast Oman (Gorin and others, 1982; Hughes-Clarke, 1988). The Huqf Supergroup contains several clastic and carbonate source rocks of exceptional quality; Huqf source rocks form the basis of the primary petroleum systems for hydrocarbons produced throughout Oman. The Cambrian Ara Formation is a carbonate/evaporite sequence with thick salt deposits (up to $1000 \mathrm{~m}$ ) (fig. 5). The thick Ara evaporites were deposited in geographically-restricted basins during periods of low relative sea level where stratified, anoxic conditions periodically prevailed and organicrich sediments and salt were deposited (Mattes and Conway-Morris, 1990; Edgell, 1991)

The lower Paleozoic section along the southern rim of the Arabian platform is comprised of mainly continental clastics, with some marine intercalations, which form important hydrocarbon reservoirs in the Ghaba and Fahud Salt Basins. A thick sequence of riftfill terrigenous and shallow-marine siliciclastics of the Haima Supergroup (Droste, 1997) overlies the Ara Formation. These sediments were 
derived mainly from the south during a period of rift-fill sagging and downloading (Al-Marjeby and Nash, 1986; Sykes and Abu Risheh, 1989; Droste, 1997). In the Ghaba Salt Basin, sediments of the Haima Supergroup fill and cover the margins of the basin reaching thicknesses in access to $6 \mathrm{~km}$ along the central axis (Droste, 1997). Pre-existing, highly variable topography caused major variations in sediment infill and syndepositional movement of the underlying salt (halokinesis) and differential subsidence across basement highs influenced thickness and lateral extent of these clastics (Aley and Nash, 1985: Heward, 1990: Loosvelt and others, 1996).

Numerous unconformities are present throughout the Paleozoic in Oman. Several erosional surfaces related to Ordovician glaciation separate transgressive open-marine to regressive deltaic cycles of the Safiq Group; however, most of the Safiq Group and overlying Silurian to Devonian is not preserved. In particular, two major and very broad uplift and erosional events in eastern Oman removed most of the Silurian and Lower Devonian sediments and the interval between mid-Devonian and Upper Carboniferous; these erosional events are recognized in deep wells from the main producing fields in the Ghaba and Fahud Salt Basins.

Late Carboniferous time is marked in Oman by glaciation and subsequent deposition of glacial clastics of the Al Khlata Formation (Levell and others, 1988) and shallow marine and fluvial clastics of the Gharif Formation, both of which comprise the Haushi Group (HughesClark, 1988) and are important hydrocarbon reservoirs throughout Oman. Clastics of the Haushi Group (fig. 5), confined mainly to interior Oman derived from southern sources, represent the transition from a dominantly clastic system to a prolonged phase of carbonate deposition.

Development of a regional shallow carbonate platform during a Middle Permian marine transgression deposited the widespread lower Khuff Formation (fig. 5) (Sharief, 1982) which forms a major regional seal above the clastic reservoirs of the Gharif Formation. Subsequent transgressions resulted in blanket deposits of the Jurassic to Cretaceous
(Cenomanian) sequence of mainly cyclic shelf carbonates over northern Oman. This includes the carbonate rocks of the Jurassic Sahtan and the Cretaceous Kahmah (Thamama) and Wasia Groups (fig. 5). In general, regional changes in sedimentation during the Jurassic and most of the Cretaceous in northern Oman were controlled mostly by eustatic fluctuations rather than tectonics. The youngest prograding carbonate sequence of this succession is the Natih Formation of latest Albian to Early Turonian. Organic-rich marls of the Natih Formation accumulated in intrashelf, restricted basins during periods of global anoxic events.

A major change in tectonic style and depositional setting took place at about the Cenomanian-Turonian boundary mostly because of collision and partial subduction of the eastern Arabian sub-plate; these compressional tectonic events are responsible for thrusting, fore-bulge, and downwarping of a foreland basin in northern Oman, ultimately forming the Omani foredeep (Loosvelt and others, 1996). Flexural extension from downwarping initiated and/or reactivated normal faulting along a northwest-southeast trend, such as those associated with Natih and Fahud fields (fig. 2). Moreover, the Late Cretaceous was a period of pronounced salt movement in the Ghaba and Fahud Salt Basins. Salt movement is associated with a large number of producing oil fields, specifically in the southeastern Arabian Gulf region in the offshore and in the onshore Ghaba and South Oman Salt basins. This structural event is also roughly coincident with a worldwide eustatic sea-level rise during the Late Cretaceous (Vail and others, 1991). Combined, these events resulted in a change from a shallow, stable platform to a deep-water marine environment. In the Ghaba and Fahud Salt Basins, a significant unconformity is present between the Wasia Group and the overlying, deeper marine, pelagic shale and carbonate facies of the thick Fiqa Formation (SantonianCampanian) of the Aruma Group (HughesClarke, 1988). Shallow-water carbonate deposition was re-established during the Maastrichtian portion of the Aruma (fig. 5). Early Tertiary sediments, including carbonates of the Hadhramaut and arid continental clastics 
and marine rocks of Fars group, disconfomably overlie the Aruma.

\section{Petroleum System Overview}

Several potential petroleum-source rocks have been identified in the stratigraphic section of Oman and range in age from Proterozoic to mid-Tertiary; however, organic-rich source rocks of Tertiary age are thermally immature (Grantham and others, 1988; 1990). Grantham and others $(1988 ; 1990)$ and Al-Ruwehy and Frewin (1998) have identified five chemically distinct types of crude oils in Oman that are best identified by distinct biomarkers and carbon isotope values. Four of these oil types are linked to source rocks from the following: 1) a broad group of oils from the Infracambrian Huqf Supergroup, 2) the Lower Silurian Sahmah Formation of the Safiq Group (Droste, 1997), 3) the Middle Cretaceous Natih Formation, and 4) the Upper Jurassic Diyab (Grantham and others, 1988; 1990) or Tuwaiq/Hanifa equivalents (Lake, 1986; Al-Ruwehy and Frewin, 1998) source. A fifth type, referred to as 'Q-type' or 'questionable source' oils, has characteristics and occurrences that suggest a separate source unit of the Huqf Supergroup (Grantham and others, $1988,1990)$ presumably prevalent in the Ghaba Salt Basin (Guit and others, 1995; Al-Ruwehy and Frewin, 1998; Richard and others, 1998a, b). The unidentified ' $Q$ ' source rock of the Huqf Supergroup is tentatively interpreted as Lower Cambrian in age (Lake, 1996) and has recently been referred to by Richard and others (1998b) as the Dhahaban source rock inverval at the top of the Ara Salt. Some geochemical characteristics of these five oil types are compared in table 1 . The geographic distribution of these oils is shown in figure 6.

Lake (1996) summarized the main source rocks of Oman and identified seven specific source- rock units within the Huqf Supergroup. These source rocks or equivalents, other than the unknown ' $\mathrm{Q}$ ' source, have been identified from well penetrations in the South Oman Salt Basin (2011); however, the presence of similar source beds is predicted to occur in portions of the Ghaba and Fahud Salt Basins. Terken (1998; in press) differentiated the major oil families of Oman using a cross plot of $\mathrm{C}_{27}$ sterane percentage versus total oil carbon isotope value (fig. 7) . Moreover, similar cross plots of oils sourced from Huqf rocks and oils produced from fields of the Ghaba and Fahud Salt Basin, referred to as North Oman Huqf oils (fig. 7), could be distinguished from oils sourced from Huqf rocks that were produced from South Oman fields (South Oman Huqf oils) (fig. 7). Therefore, based on the data of Terken (1998; in press), the term 'North Oman Huqf' oils will be used in this study to define the Total Petroleum Systems of the Ghaba and Fahud Salt Basin Provinces.

Hydrocarbon accumulations have been recognized in carbonate and clastic units throughout the stratigraphic section of the Ghaba and Fahud Salt Basins, but mostly within reservoirs of Cretaceous, CarboniferousPermian, and Cambrian-Ordovician age because of their proximity to excellent overlying seals. Major accumulations and plays have been identified in the Infracambrian Huqf Supergroup of the South Oman Salt Basin (2011) where these units can be reached by drilling (Al -Marjeby and Nash, 1986; Syke and Abu Risheh, 1989; Mattes and Conway-Morris, 1990; Boserio and others, 1995; Hartstra and Graham, 1996; Lake, 1996; Onderwaater and others, 1996; Amthor and others, 1998). Recently, potential for Huqf deep-gas in Buah Formation carbonates was revealed in the Makarem 1 (ST-2) well along the Makarem-Mabrouk High, Central Oman Platform Province of north-central Oman, suggesting further potential for other pre-salt Huqf deep-gas targets in the Ghaba and Fahud Salt Basin Provinces, particularly around salt diapirs.

The primary reservoirs of the Ghaba and Fahud Salt and their relative stratigraphic distribution and types of hydrocarbons produced are illustrated in the stratigraphic section of figure 5 . Reservoirs and associated seal rocks are also summarized in the Total Petroleum Systems Events charts of figures 8 through 10.

Traps of the Ghaba and Fahud Salt Basin Provinces are mainly structural in origin and were formed by one or more mechanisms during periodic halokinesis of the thick Cambrian Ara Salt and from consequent folding and faulting from basin loading, rifting, or other major tectonic events. This interplay of tectonics and 
salt movement was progressive, constantly modifying basin architecture, controlling sedimentation, and more crucially, modifying trap geometries (Brannan and Flanagan, 1998), particularly in the Late Cretaceous and Late Tertiary in areas where the Oman Mountains and associated foreland-basin system developed. Most of the future new-field discoveries will be focused on low-relief structures, as many of the large structures have been drilled. In contrast, although the crests of domes and anticlines above salt diapirs have been major exploration targets, salt-diapir flank traps, known to be significant exploration targets elsewhere in the world, have gone essentially untested (Faulkner, 1998).

Few pure stratigraphic traps have been identified in the fields of the Ghaba and Fahud Salt Basins. Recently, however, Richard and others (1998a, b) suggest that exploring for stratigraphic traps along the extensive ' $Q$ '-oil migration fairway (fig. 6) has the greatest potential for new Haushi reservoirs in North Oman. Although most fields in the Ghaba and Fahud Salt Basins are of structural origin, stratigraphic trapping elements are commonly involved in the formation of the accumulation. For example, accumulations in a large Cretaceous rudistid complex with a strong structural overprint in Shu'aiba reservoirs at $\mathrm{Al}$ Huwaisah field, Fahud Salt Basin, play a key role in productivity (Vahrenkamp and Grotsh, 1995). Moreover, opportunity for identifying pure- or combination-stratigraphic traps is particularly increased as improved technology and subsurface imaging provide new, higher resolution data.

\section{Hydrocarbon Exploration and Production History}

Oil exploration in Oman began in the 1920's with the first exporation license awarded for a two-year period to D'Arcy Exploration Company in 1925; however, the first discovery was not made until 1962. A concession was granted to Petroleum Development Limited (PDL) of Oman and Dhofar, an affiliate of the Iraq Petroleum Company (IPC) and Associated Companies, in 1937 covering Oman territory.
The outbreak of WWII interupted exporation activities. In the late 1940's, exploration resumed with reconnaissance studies in Dhofar. PDL relinquished the Dhofar concession and changed its name to Petroleum Development Oman (PDO). Four exploratory wells were drilled between 1956 and 1960, including the Fahud-1 well which missed the billion barrel Fahud field by less than $500 \mathrm{~m}$ (Graham and Naylor, 1996).

Oil production grew from 300,000 barrels per day $(\mathrm{bbl} / \mathrm{d})$ in 1967 through a plateau of about $500,000 \mathrm{bbl} / \mathrm{d}$ in the seventies and early eighties. During early 1998, the average daily production of oil in Oman was maximized to about 900,000 bbl/d (U.S. Energy Information Administration, 1998; Petroleum Economist, 1998; Knott, 1998); about 95 percent, or about $850,000 \mathrm{bbl} / \mathrm{d}$, is produced by the PDO consortium. Average oil production rate per well is about $400 \mathrm{bb} / \mathrm{d}$, atypical in comparison to that of about $6,000 \mathrm{bbl} / \mathrm{d}$ for other major Middle East countries. Moreover, associated produced waters are high, averaging about 2 million bbl/d in 1997, and disposal of the water presents further complications and consideration. Total exports are about 470,000 $\mathrm{bbl} / \mathrm{d}$ with an average API density of $38-39^{\circ}$, which is lighter than the common 'Oman Blend' of about $34^{\circ}$ API gravity (Petroleum Economist, 1998).

Oman's interest in the exploration for gas has been a relatively recent development with potential recoverable reserves predicted in 1997 of about 30 trillion cubic feet (tcf) in central Oman with over 10 tcf located in deep geologic structures beneath active oil fields (U.S. Energy Information Administration, 1998). Pipelines from Yibal to Muscat to Sohar carry the current gas production from 13 wells. PDO has estimated that 45 wells will be in production by the year 2000 and gas production is predicted to peak in 2003 and continue through 2025 to meet contract requirements (Petroleum Economist, 1998). Gas production and operations will be centered around three major fields of the Ghaba Salt Basin: Barik, Saih Rawl, and Saih Nihayda.

\section{TOTAL PETROLEUM SYSTEMS AND ASSESSMENT UNITS}




\section{Ghaba Salt Basin Province (2014)}

\section{North Oman Huqf/'Q' - Haushi(!) Total Petroleum System (201401)}

The North Oman Huqf/'Q' -- Haushi(!) Total Petroleum System is interpreted here as the only significant petroleum system of the Ghaba Salt Basin Province in north-central Oman. The first half of the Total Petroleum System (TPS) name implies a combination of all source beds of the Huqf Supergroup in the Ghaba Salt Basin Province. This group of source beds is referred to in this report as those units which generate the 'North Oman Huqf'- and ' $Q$ '-type oils, as defined by the stratigraphic and geochemical data of Grantham and others (1988), Sykes and Abu Risheh (1989), Richard and others (1998a, b), and Terken (1998; in press). The second half of the system name refers to the Haushi Group, which are the primary reservoirs that produce hydrocarbons from this system. Although numerous reservoirs of various age and lithology are included in this system, approximately two-thirds of the fields produce from the clastic reservoirs of the CarboniferousPermian Haushi Group. The North Oman Huqf/' $Q$ ' -- Haushi(!) TPS is summarized in the events chart of figure 8 .

Although most of the hydrocarbons produced from the Huqf source rocks are developed only within the salt basins or within the salt itself (for example, the unidentified ' $Q$ 'source rock), some source rocks of the North Oman Huqf/‘Q' -- Haushi(!) TPS are developed locally within Huqf basinal lows (Sykes and Abu Risheh, 1989; Visser, 1991; Lake, 1986; Richard and others, 1998a, b). The geographic extent of 1) the pod of active source rock, 2) minimum petroleum system, and 3) maximum or Total Petroleum System for the North Oman Huqf/' $Q$ ' -- Haushi(!) TPS are shown in figure 11. Note that the North Oman Huqf/'Q' -- Haushi(!) TPS extends beyond the the Ghaba Salt Basin Province and diagonally across the central portion of the Makaram-Mabrouk high portion of the Central Oman Platform province (2015), into the eastern flank portion of the Rub 'al Khali Basin province (2019), and southward over the Central Oman High and into the South Oman
Salt Basin province (2011). Thus, the boundary over the Makarem-Mabrouk high portion of the Central Oman Platform province (2015) separates fields that are charged by ' $Q$ ' and North Oman Huqf hydrocarbons generated mostly in the Ghaba Salt Basin proper from fields charged by hydrocarbons generated in the Fahud Salt Basin proper. The minimum petroleum system boundary is defined by known occurrence and distribution of North Oman Huqf-type and(or) 'Q'-type oils (Grantham and others, 1988; Sykes and Abu Risheh, 1989; Guit and others, 1995; Al-Ruwehy and Frewin, 1998; Richard and others, 1998a, b; and Terken, 1998; in press) in fields or wells throughout the area and interpreted here as sourced from Huqf rock units deposited within or associated with the greater Ghaba Salt Basin proper. All known oil and gas fields that occur within the minimum petroleum system boundary for the North Oman Huqf/' $Q$ ' -Haushi(!) TPS are listed in table 2. The boundary for the Total Petroleum System defines the maximum areal extent of occurrence of genetically-related, Ghaba Salt Basin, Huqfand ' $Q$ '-sourced hydrocarbons. Depth to Huqf source rocks within the TPS boundary likely ranges from about $4,000 \mathrm{~m}$ to $>10,000 \mathrm{~m}$.

\section{Reservoirs, seals, and trap styles}

Names and ages of reservoirs of the North Oman Huqf/'Q' -- Haushi(!) TPS and corresponding seals and hydrocarbons produced are summarized in figures 5 and 8 . The primary reservoirs are two formations of the Middle Carboniferous to Lower Permian Haushi Supergroup - the Al Khlata and the Gharif. The glacio-lacustrine $\mathrm{Al}$ Khlata Formation consists of laterally continuous sandstones, intercalated with thin shale layers which have no sealing capacity (Levell and others, 1988). The regionally deposited Rahab Shale at the top of the $\mathrm{Al}$ Khlata stratigraphic boundary and between the Al Khlata and Gharif Formations commonly forms a seal for Al Khlata reservoirs (fig. 5). In most fields, however, the Al Khlata Formation and laterally-continuous, porous deltaic sands of the Lower Gharif form one continuous reservoir and are sealed by 20 to 30 
$\mathrm{m}$ of the Haushi Limestone member (Guit and others, 1995; Nederlof and others, 1995). Middle Gharif reservoirs are composed of fine-grained sandstones, siltstones, and shales with up to 20 percent porosity but with low permeability and are sealed with a thick (about $90 \mathrm{~m}$ ) claystone. Alluvial, mostly laterally-discontinuous channel sands of the Upper Gharif are sealed by basal carbonates of the Lower Khuff Formation (Guit and others, 1995; Nederlof and others, 1995).

Other major reservoirs are porous, commonly fractured, grainstones and chalky carbonates of the Middle Cretaceous Natih Formation (Fiqa Formation shale seal) and Lower Cretaceous Shu'aiba Formation (Nahr Umr Formation shale seal) (fig. 5). Sandstones of the Barik sandstone member (Mabrouk Shale seal) and Miqrat Formations (Al Bashair Shale seal), Haima Supergroup (L. Cambrian to L. Ordovician) are primarily deep gas reservoirs; potential for deep gas is also being explored in Precambrian carbonates of the Buah Formation, Huqf Supergroup (fig. 5).

Most of the fields of the Ghaba Salt Basin, particularly those producing from Haushi reservoirs, are structurally complex, saltinduced anticlines and domes that have been broken up into several fault blocks by crestal collapse features (Nederlof and others, 1995). Specific common trap styles are faulted closures, dip closures, and faulted-dip closures (Lake, 1996).

\section{Source rock character and geochemistry}

Infracambrian Huqf source rocks contain structureless, type I and type II oil-prone organic matter (Grantham and others 1988, 1990; Mattes and Conway-Morris, 1990; Lake, 1996). Huqf source rocks produce a rather broad group of North Oman Huqf-type oils which are recognized by having high abundances of of $\mathrm{C}_{29}$ steranes (greater than 50 percent) relative to other steranes and $\partial^{13} \mathrm{C}$ measured at $-37.1 \%$. South Oman Huqf-sourced oils can be distinguished from North Oman Huqf-sourced oils in cross-plots of isotopic and $\mathrm{C}_{27}$ sterane percent compositions (fig. 7). North Oman Huqf oils have ${ }^{13} \mathrm{C}$ compositions between $-31 \%$ o and $-35 \%$ and $C_{27}$ sterane as high as 45 or $50 \%$, whereas South Oman Huqf oils are between $35 \%$ and $-37 \%$ ond $\mathrm{C}_{27}$ sterane $<25 \%$. Richard and others (1998a, b) have identified the Shuram Formation of the Huqf Supergroup as the primary source of Huqf oils in Haushi reservoirs of north Oman. The Shuram contains carbonate source rocks that are thick (about $450 \mathrm{~m}$ ), laterally extensive, and average about $2 \%$ TOC (Lake, 1996).

The main geochemical characteristics of the Huqf-type oils, which correlate well with extracts from Huqf source rocks, are high sulfur (1.5-2.0\%) content, the presence of a homologous series of long chain, methyl substituted alkanes, the so-called ' $X$ '-branched compounds (Klomp, 1986), high (45-90\%) $C_{27}$ sterane percent, and high-negative (-28 to $-33 \%$ ) carbon isotope. The geochemical character- istics of North Oman Huqf-type and ' $Q$ '-type oils are summarized in table 1.

The ' $Q$ '-type oils were first identified by Grantham and others (1988) from fields in central Oman and later by Sykes and Abu Risheh (1989), Guit and others (1995), AlRuwehy and Frewin (1998), and a, b and others (1998) in more northern fields. These commonly light (average API gravities of about 40), relatively low-sulfur (about $0.2 \%$ ), mature oils are found in Paleozoic clastic reservoirs and occur where Huqf Group rocks are deeply buried, at depths greater than those routinely penetrated by drilling, and unsampled. The ' $Q$ ' oils also contain the so called ' $X$-compounds', evidence which argues for the presumed Infracambrian age of the ' $Q$ ' source rock. Grantham and others (1990) and Guit and others (1995) speculate that the distinctive ' $Q$ ' oil is from a source rock in an undrilled Huqf level, had a specific flourishing biomass, contained type I and type II organic matter, and is present in a limited extent within the salt in the Ghaba Salt Basin. Other specific source rock characteristics, such as thickness and TOC, of the ' $\mathrm{Q}$ ' source rock(s) are still unknown. The ' $\mathrm{Q}$ '-sourced oils are recognized by having a high $(>50 \%)$ total $\mathrm{C}_{27}$ sterane abundance relative to other steranes and ${ }^{13} \mathrm{C}$ measured at $-30.4 \%$. Additionally, the ' $Q$ ' oils have a distinctive compound which is not found in other oils and yet to be identified in a known source rock (Al- 
Ruwehy and Frewin, 1998). Pure 'Q' oil end members have been identified in Haima and Natih reservoirs in Saih Rawl and Bahja fields.

Most oil accumulations in central Oman are probably mixtures from both Huqf and ' $Q$ ' source rocks. Commonly, ' $Q$ ' oils are found in continuous strings of accumulations below the regional Khuff seal on northerly plunging structural highs. The Huqf oils, however, are found at all stratigraphic levels in structures related to salt domes and fault zones (Guit and others, 1995) suggesting a vertical mechanism for Huqf hydrocarbons as opposed to a predominantly horizontal migration for ' $Q$ ' oils.

\section{Burial history, generation, and migration}

Generation of hydrocarbons from Huqf source rocks in north and central Oman has been discussed by Sykes and Abu Risheh (1989), Visser (1991), Guit and others (1995), Borgomano and others (1996), Droste (1997), and Amthor and others (1998). Burial history curves for the North Oman Huqf source rocks in the Ghaba Salt Basin Province are shown in figures 12 and 13.

Vitrinite reflectance equivalent (VRE) of Huqf source rocks within the North Oman Huqf/' $Q$ ' -Haushi(!) TPS ranges from about $0.6 \%$ to $4.0 \%$ (Sykes and Abu Risheh, 1989; and Visser (1991). Basin modeling by Amthor and others (1998) suggests three periods of hydrocarbon generation in the Ghaba Salt Basin: (1) during Haima (Andam-Safiq) deposition (about 520 $373 \mathrm{Ma}) ;(2)$ during Akhdar-Kahmah deposition (270 - $100 \mathrm{Ma}$ ); and (3) during Aruma/Tertiary deposition (80 - $0 \mathrm{Ma}$ ). Deep reservoirs of the Haima Supergroup were charged with oil mainly during the second stage. Gas was generated by Huqf sources as early as $510-375$ $\mathrm{Ma}$ in the central Ghaba Salt Basin. Gas generated during the second stage was sourced on the west flank of the Ghaba Salt Basin and migrated mainly east into Haima structures along the western margin of the basin. Downbuilding of salt in the deeper central Ghaba Salt Basin inhibited migration of the western flank gas charge from reaching structures along the eastern margin of the basin.
Stratigraphic distribution of the Huqf source rocks relative to the Ara Salt (i.e., pre-salt, intrasalt, post-salt) and salt movement also plays a critical role in the migration and charging of reservoirs. For example, modeling by Borgomano and others (1996) in the Ghaba Salt Basin shows at least two stages of Huqf oil generation and reservoir charge with subsequent Huqf gas generation and gas flushing of the second stage of oil charge.

' $Q$ ' oils are speculated to be sourced within the Ghaba Salt Basin (Grantham and others, 1988; Sykes and Abu Risheh, 1989; Visser, 1991; Guit and others, 1995; Richard and others, 1998a). However, Richard and others (1998b) more recently suggest from seismic data that the ' $Q$ ' oils may in fact be derived from two different "kitchens": 1) a source along the western margin of the Ghaba Salt Basin, and 2) a possible source in the south Fahud Salt Basin. In these presumed ' $Q$ '-source kitchens, ' $Q$ ' charge appears to postdate Huqf charge with Huqf oils generated as early as Ordovician (Visser, 1991). Older structures in the Ghaba Salt Basin and closest to the ' $\mathrm{Q}$ ' source rock seem to have been flushed later with light ' $Q$ ' oil with lateral migration along north-south trending structural highs. Migration of ' $Q$ ' oils was thus through the Gharif section in a southerly direction gradually moving into stratigraphically younger units and over a distance of more than $150 \mathrm{~km}$ (Guit and others, 1995). Moreover, faulting during the latest Tertiary has caused breaching of the main Khuff seal, allowing vertical migration of Huqf oils into younger, post-Upper Cretaceous structures. Thus, pure Huqf-type oils are found in fault-related structures where pathways for the lateral migration of ' $Q$ ' oils have been blocked. The geographic distribution of known Huqf and ' $Q$ ' oil accumulations, including admixtures of both, is shown in figure 6.

Oil typing in northern Oman shows that over $90 \%$ of oil in place in Haushi reservoirs is derived from the ' $Q$ ' source rock. The ' $Q$ ' kitchen was defined using chemical "odometers" (mainly nitrogen) which provide a measure of migration distance (Richard and others, 1998a, b). Chemical odometer tracing from 18 'Q' oils suggests that the ' $Q$ ' source may be located on the western margin of the Ghaba 
Salt Basin, in the vicinity east of Saih Rawl field (fig. 2). Seismic lines across this area show saltfilled rim synclines which possibly contain the ' $Q$ ' source beds. Also, the second possible source area in the Fahud Salt Basin is marked on seismic with a high amplitude reflector at the top of the Ara Salt (Richard and others, 1998b). Both source areas are considered to have been restricted areas during Ara deposition and ideal sites for source rock preservation. The high efficiency of the main overlying seal, the Khuff Formation, has allowed for long distance migration of ' $Q$ ' oils, as demonstrated by chemical odometers, and the new-field discoveries along the ' $Q$ '-migration fairway (fig. 6).

Modeling of hydrocarbon generation for the top-salt Dhahaban (' $\mathrm{Q}$ ') source-rock interval by Richard and others (1998b) indicates that ' $Q$ ' oil was generated in the Ghaba Salt Basin source area in the Paleozoic and Mesozoic and peaked in the Middle Paleozoic and Triassic. In the shallower southernmost portion of th Fahud Salt Basin to the west, ' $Q$ ' oil generation occurred from the Jurassic until Early Tertiary peaking twice during the Early and Late Cretaceous.

Biodegraded, low API $\left(<20^{\circ}\right)$ gravity oils are produced from Haushi and Haima Group reservoirs in an area along the east-northeast flank of the Ghaba Salt Basin. Al Lamki and Terken (1996) have shown that these reservoirs are also major aquifers and are in hydraulic communication. Hydrodynamic activity in the Ghaba Salt Basin has reduced temperatures and salinities of formation waters where recharge has occurred over the history of the basin degrading the oils. Recharge of meteoric waters produces a geochemical environment conducive for biodegradation by oil-reducing bacteria in hydrocarbon-bearing reservoirs by reducing reservoir temperatures (and geothermal gradient) and carrying oxygen and nutrients. Moreover, areas of highly mature oils in the Ghaba Salt Basin also define the southwardmigrating ' $Q$ '-oil fairway (fig. 6) that was not affected by biodegradation.

\section{Ghaba-Makarem Combined Structural Assessment Unit (20140101)}

One all inclusive assessment unit, designated as the Ghaba-Makarem Combined Structural Assessment Unit, has been assigned to the North Oman Huqf/'Q' -- Haushi(!) TPS of the Ghaba Salt Basin Province. The assessment unit boundary is defined and described by the TPS boundary and includes all reservoirs (Haima, Haushi, Shu'aiba, Natih, among others) and styles of structural traps (domes, anticlines, fault blocks, etc.) of the known inclusive fields (fig. 8; table 2). Thus, the Ghaba-Makarem Combined Structural Assessment Unit boundary outlines the maximum geographic extent at which similar undiscovered fields may exist in the North Oman Huqf/'Q' -- Haushi(!) TPS (fig. 11).

Expected exploration strategies and areas of new-field discoveries in this assessment unit are:

1. new-field discoveries for deep gas/condensate $(>5000 \mathrm{~m})$ in clastic reservioirs of the Haima Supergroup and possibly deeper limestone reservoirs of the Buah Formation, Huqf Supergroup, in north-central Oman

2. growth of proven gas/condensate reserves from Haima Supergroup in existing fields (field growth).

3. salt diapir flank traps in Natih, Shu'aiba, Haushi, and Haima targets (see Faulkner, 1998)

4. new fields in Haushi (Al Khlata and Gharif) clastics, particularly within the ' $Q$ ' oil migration fairway (fig. 6).

5. new fields in Shu'aiba and Natih limestones in low-relief, fractured 'pancake' structures (large structures already drilled).

6. growth of proven oil reserves in existing fields (field growth).

Limitations, conditions, and risks that will affect areas of exploration, particular plays, and sizes and numbers of fields include:

1. the occurrence of pore-plugging pyrobitumen in Haima reservoirs in areas along Makarem-Mabrouk high.

2. low $\left(15-20^{\circ}\right)$ API, biodegraded oils in Haushi and Haima reservoirs in areas close to meteoric recharge, particularly along eastsoutheast flank of the Ghaba Salt Basin and in Huqf-Haushi Uplift Province (2013).

3. substantial risk of low quality (nitrogen rich) gas along Oman Mountain front and overthrust.

It is predicted in this study that a large portion of the exploration efforts in north-central 
Oman will be focused on deep gas/condensate resources in Haima, and possibly Huqf, reservoirs. Because much of the gas resource is likely to be discovered in existing fields, a large gas growth factor, the Mid-Continent growth factor derived from the U.S.Geological Survey 1995 National Oil and Gas Assessment (J.W. Schmoker, USGS) was used in the assessment of resources.

\section{Fahud Salt Basin Province (2016)}

\section{North Oman Huqf - Shu'aiba(!) Total Petroleum System (201601)}

The North Oman Huqf - Shu'aiba(!) Total Petroleum System is interpreted here as the dominant petroleum system of the Fahud Salt Basin Province of north Oman and overlaps, in part, with the Middle Cretaceous Natih(!) TPS discussed in the following section. The first half of the TPS name implies a combination of all source beds of the Huqf Supergroup in the Fahud Salt Basin Province which generate the 'pure Huqf-type" oils, referred to here as 'North Oman Huqf' -type, as defined by the stratigraphic and geochemical data of Grantham and others (1988), Sykes and Abu Risheh (1989), Richard and others (1998a, b), and Terken (1998; in press). The second half of the system name refers to the carbonate reservoirs (porous rudist buildups and fractured chalk) of the Cretaceous Shu'aiba Formation, which to date have produced most of the hydrocarbons generated from this system (for example, Yibal field, Knott, 1998). Similar to the North Oman Huqf/' $Q$ ' -Haushi(!) TPS, numerous reservoirs of various age and lithology are included in this system and are summarized in figure 5. Approximately one-third of the fields produce from Shu'aiba reservoirs; however, in-place reserves from the high porosity, low permeability, fractured Shu'aiba at Yibal field alone are estimated at about 3 billion barrels of "stocktank oil" (Alsharan and Nairn, 1997). The North Oman Huqf -- Shu'aiba(!) TPS is summarized in the events chart of figure 9 .

Most of the hydrocarbons produced from the Huqf source rocks are developed within the Infracambrian salt basin with some source rocks developed locally within Huqf basinal lows (Sykes and Abu Risheh, 1989; Visser, 1991; Lake, 1986; Richard and others, 1998a, b). The geographic extent of 1) the pod of active source rock, 2) minimum petroleum system, and 3) maximum or Total Petroleum System for the North Oman Huqf -- Shu'aiba(!) TPS all coincide and are shown in figure 14 . The North Oman Huqf -- Shu'aiba(!) TPS is interpreted here to extend beyond the the Fahud Salt Basin Province boundary and onto the central portion of the Makaram-Mabrouk high of the Central Oman Platform Province (2015). A small portion of the system also extends into the eastern flank portion of the Rub 'al Khali Province (2019). Thus, the boundary onto the Makarem-Mabrouk high, Central Oman Platform Province, indicates that some fields, particularly deep gas fields, are charged from Huqf hydrocarbons generated within the Fahud Salt Basin (Amthor and others, 1998). The minimum petroleum system boundary is defined by the known occurrence and distribution of North Oman Huqf-type oils (Grantham and others, 1988; Sykes and Abu Risheh, 1989; Guit and others, 1995; Al-Ruwehy and Frewin, 1998; Richard and others, 1998a, b; and Terken, 1998; in press) in fields or wells throughout the area and interpreted here as sourced from Huqf rock units deposited within, or in association with, the greater Fahud Salt Basin proper. All known oil and gas fields that occur within the minimum petroleum system boundary for the North Oman Huqf-Shu'aiba(!) TPS are listed in table 2. The Total Petroleum System boundary for the North Oman Huqf -- Shu'aiba(!) TPS is defined as the maximum areal extent of hydrocarbons generated by Huqf source rocks of the Fahud Salt Basin proper. The estimated range of depth to Huqf source rocks within the TPS boundary interpreted from the published structure contour maps of Sykes and Abu Risheh (1989) is 5,000 m to $>8,000 \mathrm{~m}$. 


\section{Reservoirs, seals, and trap styles}

Names and ages of reservoirs of the North Oman Huqf -- Shu'aiba(!) TPS and corresponding seals and hydrocarbons produced are summarized in figures 5 and 9 . Over 90 percent of the fields in the Fahud Salt Basin, half of which are gas fields, produce from the high porosity, commonly fractured, grainstones and chalky carbonates of the Lower Cretaceous Shu'aiba Formation and Middle Cretaceous Natih Formation. Although some fields producing from Natih reservoirs are sourced by the organic-rich facies of the Natih Formation (the Natih(!) Total Petroleum System discussed later), a large volume of oil and gas in Natih reservoirs is sourced from the Huqf. Most production, however, is from the Shu'aiba Formation (Thamama-Khamah Group, Early Aptian) (Murris, 1980; Alsharhan and Nairn, 1997). The Shu' aiba is overlain by the Nahr Umr Formation of the Wasia Group, a widespread transgressive shale, which forms a regional seal for these reservoirs (fig. 5). The intergrity of this seal is excellent as hydrocarbons produced from the Shu'aiba are commonly different from those produced in Middle Cretaceous Natih reservoirs overlying the Nahr Umr shales (Brennan, 1985). In both the Shu'aiba and Natih Formations, shallow-water, shelf-margin carbonate buildups (mainly rudistid reefs) and associated grainstones (debris shoals) formed on and around low relief structural highs (mostly formed by salt pillows and tilted, upthrown fault blocks) comprise the best reservoirs (Frost and others, 1983; Harris and Frost, 1984). Uplift from both tectonic and halokinetic movements produced secondary (mostly moldic and vuggy) porosity from subaerial erosion and meteoric diagenesis. Porosities ranging from 30 to 40 percent have been recorded in the Shu'aiba at Yibal, Al Hawaisah, Natih, Fahud, and Daleel fields.

Sandstones of the Haushi Group (Gharif and Al Khlata Formations-Khuff limestone seal) form reservoirs in some fields. The Barik sandstone member (Mabrouk Shale seal) and Miqrat Formations (Al Bashair Shale seal) of the Lower Cambrian to Lower Ordovician age parts of the Haima Supergroup are primarily deep gas reservoirs with reservoir potential recently recognized in Precambrian carbonates of the Buah Formation.

Similar to the Ghaba Salt Basin, most of the fields of the Fahud Salt Basin are structurally complex, salt-induced anticlines and domes that have been broken up into several fault blocks by crestal collapse features (Nederlof and others, 1995). Specific common trap styles are faulted closures, dip closures, and faulted-dip closures (Lake, 1996).

\section{Source rock character}

The geochemical characteristics of North Oman Huqf-type oils are discussed in the previous section on the North Oman Huqf/' $Q$ ' -Haushi(!) TPS and are also summarized in table 1. North Oman Huqf oils have $\partial^{13} \mathrm{C}$ compositions between about $-33 \%$ and $-35 \%$ and $\mathrm{C}_{27}$ sterane from 10 to $45 \%$ and can be distinguished other Huqf-sourced oils (i.e., South Oman Huqf and ' $Q$ ' types, see fig. 7).

\section{Burial history, generation, and migration}

Generation of hydrocarbons from Huqf source rocks in north and central Oman has been discussed by Sykes and Abu Risheh (1989), Visser (1991), Guit and others (1995), Borgomano and others (1996), Droste (1997), and Amthor and others (1998). Burial history for the North Oman Huqf source rocks in the Fahud Salt Basin Province is shown in figures 15 and 16.

Vitrinite reflectance equivalents of Huqf source rocks within the the North Oman Huqf -Shu'aiba(!) TPS ranges from about 2.0 to 4.0 percent (Sykes and Abu Risheh, 1989; and Visser (1991). Burial history reconstructions by Visser (1991) suggest that an early minor stage of oil generation occurred in Middle and Lower Huqf source rocks during the early Silurian (fig. 15). Peak oil generation occurred during Late Permian/Early Triassic ( 250 ma); gas generation began during the Cretaceous ( 110 Ma). Modelling by Amthor and others (1998) suggest that gas expelled from Huqf source rocks in the Fahud Salt Basin charged structures across the Fahud Salt Basin and reached the 
Makarem high during a period ranging from 80 Ma to present day (fig. 16).

\section{Fahud-Huqf Combined Structural Assessment Unit (20160101)}

One all-inclusive assessment unit, designated as the Fahud-Huqf Combined Structural Assessment Unit, has been assigned to the North Oman Huqf -- Shu'aiba(!) TPS of the Fahud Salt Basin Province. The assessment unit boundary is defined and described by the Total Petroleum System boundary and includes all reservoirs (Haima, Haushi, Shu'aiba, Natih, among others) and styles of structural traps (domes, anticlines, fault blocks, etc.) of the known inclusive fields that produce hydrocarbons from Huqf sources in the Fahud Salt Basin proper (fig. 14, table 2). Thus, the assessment unit boundary outlines the maximum geographic extent at which similar undiscovered fields may exist in the North Oman Huqf -- Shu'aiba(!) TPS. The Fahud-Huqf Combined Structural Assessment Unit shares a common border to the south-southeast with the Ghaba-Makarem Combined Structural Assessment Unit (20140101) of the North Oman Huqf/‘Q' -- Haushi(!) TPS (201401).

Similar to the Ghaba-Makarem Combined Structural Assessment Unit (20140101), expected exploration stategies and areas of new-field discoveries in this assessment unit are:

1. extension of Haima (Barik, Miqrat, etc.) deep-gas/condensate play into the Fahud Salt Basin with new-field discoveries at depths $>5000 \mathrm{~m}$; some additional targets may also be discovered in reservoirs of the underlying Buah Limestone, Huqf Supergroup.

2. growth of proven gas/condensate reserves from Haima Supergroup in existing fields (field growth).

3. extension of exploration into Fahud Salt Basin for new oil fields and oil-field growth within clastic reservoirs of the Haushi Group (Al Khlata and Gharif).

4. new fields in Shu'aiba and Natih limestones in fractured, low-relief, 'pancake' structures (all large structures have been drilled) in western portion of assessment unit and along western border of Oman, eastern- flank portion of the Rub 'al Khali Province (2019).

5. growth of proven oil reserves in all reservoirs of existing fields (field growth).

It is predicted in this study that a large portion of the exploration efforts in Fahud Salt Basin Province will focus on the Haima Supergroup, and possibly Huqf Supergroup, deep-gas/condensate play. Because much of the gas resource is likely to be discovered in existing fields, a large gas growth factor, the MidContinent growth factor derived from the U.S.Geological Survey 1995 National Oil and Gas Assessment (J.W. Schmoker, USGS) was used in the assessment of resources.

Size and number of new economic discoveries may be limited by or dependent on the following:

1. seismic resolution of low relief structures and presence/absence of fractures or leaching in Shu'aiba reservoirs with smaller closure.

2. reduced porosity in deep Gharif targets (Guit and others, 1995) in Fahud Salt Basin which are likely to contain gas rather than oil.

3. thin, poor quality, and commonly the presence of pore-plugging bitumen in Haima deep-gas reservoirs in the Fahud Salt Basin.

4. poor quality, high-nitrogen content of gas along Oman Mountain front and overthrust.

\section{Middle Cretaceous Natih(!) Total Petroleum System (201602)}

Although about 80 percent of the hydrocarbons produced in Oman are thought to be generated by source rocks of the Infracambrian Huqf Supergroup (Sykes and Abu Risheh, 1989), the Middle Cretaceous Natih(!) TPS is a smaller (about $20,000 \mathrm{~km}^{2}$ in geographic extent) but highly-efficient petroleum system (Terken, 1998; in press). The Natih(!) TPS is contained primarily (78 areal percent) within the Fahud Salt Basin Province with an estimated in-place resource volume of some 9 BBOE (Terken, 1998: in press); this inplace volume is exclusive of hydrocarbons generated by Huqf sources. About 2 billion barrels of discovered recoverable reserves attributed to the Middle Cretaceous Natih(!) TPS are concentrated in Fahud and Natih fields. 
The geographic extent of 1) the pod of active source rock, 2) minimum petroleum system, and 3) Total Petroleum System for the Natih(!) TPS are shown in figure 17 . The pod of active source rock was determined from a series of burial history reconstructions, geothermal gradients, and thermal maturity data (mostly vitrinite reflectance). The minimum petroleum system boundary incorporates the pod of active source rock and all known fields and oils shows from wells that have produced 'Natih-type' oil. The maximum extent of the Middle Cretaceous Natih(!) TPS is structurally bound to the north by the Oman Mountains, to the south and southwest by the Late Cretaceous to Tertiary foreland bulge, and to the southeast by the the salt-structured core of the Ghaba Salt Basin (figs. 2 and 17).

\section{Source rock lithology and geochemistry}

The $400 \mathrm{~m}$-thick carbonate sequence of the Natih Formation is comprised of seven lithologic subdivisions designated A through G. Two organic-rich shaley intervals, the Natih ' $B$ ' and ' $\mathrm{E}^{\prime}$ units, that are easily identified on well logs and of limited geographic extent, have sourced the hydro- carbons of the Natih(!) TPS. In particular, the 500-meter-thick Natih ' $\mathrm{B}$ ' unit is of excellent source rock quality having TOC contents as high as 15 weight percent and averaging about 5 percent. These units contain predominantly structureless TypeI/II organic matter (Grantham and others, 1988; van Buchem and others, 1996; Terken, in press).

Natih oils have an API gravity of about $32^{\circ}$ and are distinctly different in geochemical composition than other oils in Oman. Natih oils have similar contributions from $C_{27}, C_{28}$, and $C_{29}$ steranes rather than a particular dominance of one, which is characteristic of Huqf and ' $Q$ ' oils (table 1). Modeling by Terken (1998; in press) indicates that only minor gas has been generated from these oil-prone, Natih source rocks.

\section{Reservoirs, seals, and trap styles}

Porous (30-40 percent) carbonates of the Natih A, C, D, and E intervals constitute the reservoirs for oils generated by Natih source rocks. Lithoclast and skeletal grainstone aprons (shoals) and rudist packstone bioherms, where fresh-water leaching has enhanced porosities, comprise many of the Natih reservoirs (Harris and Frost, 1984). In contrast, Natih field itself produces from heavily fractured, low permeability $(0.5$ to $10 \mathrm{md})$, chalky limestones (Whyte, 1995; Terken, 1998). Individual Natih reservoirs are sealed by the intra-formational marls and shales; a thick shale sequence of the overlying Fiqa Formation (fig. 5) forms a major regional seal for the Natih Formation. Natih oils are also found in the Shu'aiba Formation in fault-dip structures of Natih and Fahud fields. Natih oils in these fields are explained by juxtaposition against marginally mature Natih source rocks (Terken, 1998; in press). Future exploration may focus on potential reservoirs within the overlying Fiqa Formation where possible turbidite strati- graphic traps and truncation traps below Lower Fiqa shales have been recognized (Lake, 1996; Terken, 1998).

Most traps are structural and related to development of the foreland basin during the Late Cretaceous/Tertiary. These structures formed during two major stages of tectonics that built the Oman Mountains. Obuction and deformation during the first alpine event produced normal and strike-slip faults while the second alpine event resulted in reactivation and inversion of earlier faults near the thrust front, most of which were enhanced by halokinesis during these events (Loosvelt, 1996; Terken, 1998; in press).

\section{Burial history, generation, and migration}

The burial and thermal history of Natih source rocks has been discussed by Harris and Frost (1984), Terken (1998; in press) and, to a lesser degree, by Visser (1991). Additional data, information, and diagrams on thermal maturity, as confidential reports contributed from major oil companies, were also incorporated into our study. Burial history of the Natih Formation is illustrated in figures 18 and 19 and also 
summarized in the petroleum system events chart of figure 10.

The Natih 'kitchen' is defined where the extent of the organic-rich facies is present in the deepest parts of the foreland basin. The pod of active source rock was originally assigned using a series of burial history diagrams and approximated at the 2,000-meter-depth structure contour of the Natih Formation; however, subsequent modifications were made after later reports and communications with J.M.J. Terken (1998, Petroleum Development Oman). Terken (1998, in press) describes a shallower extension of active source rock of lesser thermal maturity to the east of the Fahud and Natih faults and along the Maradi Fault zone (fig. 1) which is an area of high (up to $28^{\circ} \mathrm{C} / \mathrm{km}$ ) geothermal gradient.

The thickness of the massive Fiqa shale seal and modest folding and thrusting of the Oman Mountains forced lateral migration of Natih oils. Modeling of the Natih by Terken (1998, in press) shows that migration was initially towards the foreland bulge and Ghaba Salt Basin but was interrupted by the formation of the Fahud fault during early development of the foreland basin. The fault thus created a shadow zone preventing migration of Natih oils to reach the foreland bulge and into Yibal and Al Huwaisah fields (fig. 2). The Natih structure, however, formed during the second alpine event and subsequently deflected the hydrocarbon charge from the Fahud field. The high integrity of the massive Fiqa top seal has allowed hydrocarbons to be retained in these shallow, large-throw fault-dip structures. Only minor gas has been generated from this highly oil-prone source with some gas migration towards the Lekhwair area and Maradi Fault zone (Terken, 1998, in press).

\section{Natih-Fiqa Structural/Stratigraphic Assessment Unit (20160201)}

One all-inclusive assessment unit, designated as the Natih-Fiqa Structural/Stratigraphic Assessment Unit, has been assigned to the Middle Cretaceous Natih(!) TPS of the Fahud Salt Basin Province. The assessment unit boundary is defined and described by the Total Petroleum System boundary and includes all known fields and wells that produce oils, or have oil shows, that have been identified geochemically as Natih sourced (fig. 16, table 2). Thus, the Natih-Fiqa Structural/Stratigraphic assess- ment unit boundary outlines the maximum geographic extent at which similar undiscovered fields may exist in the Middle Cretaceous Natih(!) TPS and is independent of the North Oman Huqf -- Shu'aiba(!) TPS (201601).

At present, only eight fields (table 2) are allocated to the Middle Cretaceous Natih(!) TPS and Natih-Fiqa Structural/Stratigraphic Assessment Unit with most of the recoverable oil in the two giant fields, Fahud and Natih. Subsequently, only smaller, marginally economic discoveries were made in fields along the Maradi Fault zone. Shows of Natih oils have also been identified in at least seven other fields or wells (Terken, in press).

Exploration and new-field discoveries in this assessment unit are estimated using the data and interpretations of Lake (1996), Loosvelt and others (1996), and Terken (in press). Future discoveries will be from more subtle trap syles including:

1. structural traps related to foreland basin development that include faulted-dip/truncation closures on the northern flank of the foreland bulge, and traps above salt domes with late Tertiary movement.

2. stratigraphic traps within Natih carbonate buildups.

3. stratigraphic traps in unproven turbidites or other marine clastics in Fiqa Formation, foreland basin area.

Size and number of new economic discoveries may be limited due to:

1. presence/absence of the massive top Fiqa shale seal.

2. limited areal extent and maturity of Natih organic-rich facies in Late Cretaceous foredeep.

3. charge shielding by major fault zones of laterally-migrated Natih oils into distal structures.

\section{SUMMARY}

Three Total Petroleum Systems and their associated assessment units have been interpreted in this study for the Ghaba and 
Fahud Salt Basin Provinces of north-central Oman. The boundary for each Total Petroleum System also defines a boundary that corresponds to an assessment unit and incorporates all trap styles and reservoirs of the produced hydrocarbons.

In both the Ghaba and Fahud Salt Basins, hydrocarbons were generated from several deeply-buried source-rock units of the Infracambrian Huqf Supergroup. Although one general 'North Oman Huqf' type oil is dominant in the Fahud Salt Basin, oils in the Ghaba Salt Basin can be linked to at least two distinct Huqf source-rock units, commonly found as admixtures, the general North Oman Huqf-type oil source and a more dominant 'questionable unidentified-source' or ' $Q$ '-type Huqf oil source.

Hydrocarbons generated from Huqf sources are produced from a variety of reservoir types and ages in both the Ghaba and Fahud Salt Basin Provinces. Clastic reservoirs of the Gharif and Al Khlata Formations, Haushi Group (M. Carboniferous to L. Permian), dominate oil production in the Ghaba Salt Basin Province. In contrast, Cretaceous carbonates of the Shu'aiba and Natih limestones account for most of the production in the Fahud Salt Basin. Deep gas is produced mainly from Middle Cambrian to Lower Ordovician clastic reservoirs of the Haima Supergroup with future potential in deeper Huqf reservoirs. Traps are mainly structural in origin and were formed by one or more mechanisms during periodic halokinesis of the thick Cambrian Ara Salt beginning with the deposition of the thick Haima clastics and from consequent folding and faulting from basin loading, rifting, and tectonics forming the Oman Mountains and associated foreland-basin system during the Late Cretaceous-Early Tertiary. Most of the future new-field discoveries will likely target low-relief structures, as many of the large structures have been drilled, and will target deep gas in the Haima and Huqf Supergroups.

The Middle Cretaceous Natih Total Petrolum System is a small efficient system of the Fahud Salt Basin Province producing primarily from Natih reservoirs along fault-dip structures. Most traps are structural and are related to development of the foreland basin and formation of the Oman Mountains. Future targets will be less obvious than those of Fahud and Natih fields and frontier exploration in stratigraphic traps within Natih buildups and in unproven turbidite and other marine clastics of the Fiqa Formation.

\section{References Cited}

Al Lamki, M.S.S., and Terken, J.J.M., 1996, The role of hydrogeology in Petroleum Development Oman: GeoArabia, v. 1, p. 495510.

Al-Marejby, A. and Nash, D., 1986, A summary of the geology and oil habitat of the Eastern Flank Hyrocarbon Province of south Oman: Marine and Petroleum Geology, v. 3, p. 306314.

Al-Ruwehy, N., and Frewin, N.L., 1998, Oil families in Oman: GeoArabia, v. 3., p. 54-55.

Aley, A.A., and Nash, D.F.,1985, A summary of the geology and oil habitat of the Eastern Flank Hydrocarbon Province of south Oman: OAPEC seminar on source and habitat of petroleum in the Arab countries, Kuwait, p. 521-541.

Alsharhan, A.S., and Nairn, A.E.M., 1997, Sedimentary Basins and Petroleum Geology of the Middle East: Elsevier Science B.V., Amsterdam, 843 pp.

Amthor, J.E., Smits, W., Nederlof, P. and Lake, S., 1998, Prolific oil production from a source rock -- The Athel silicilyte sourcerock play in south Oman: Abstracts, Amer. Assoc. Petrol. Geol. 1998 Annual Meeting, Salt Lake City, One CD-ROM.

Beydoun, Z.R., 1991, Arabian Plate Hydrocarbon Geology and Potential--A Plate Tectonic Approach: American Association Petroleum Geologist Studies in Geology No. 33, 77 p.

Boote, D.R.D., Kou, D., and Waite, R.I., 1990, Structural evolution of the Suneinah Foreland: in Robertson, A.H.F., Searle, M.P., and Ries, A.C., eds., The Geology and Tectonics of the Oman Region: Geological Society of London Special Publication 49, p. 397-418.

Borgomano, J.R.F., Amthor, J., Terken, J., and van der Zwan, K., 1996, Diagenesis of Barik Sandstone reservoirs, Haima Supergroup in North Oman--Role of sedimentology, burial and charge history: Exporation in Oman -- 
New Ideas from Old Basins, Petroleum Development Oman, p. 73-77.

Boserio, I.A., Kapellos, C., and Priebe, H., 1995, Cambro-Ordovician tectonostrati-graphy and plays in the South Oman Salt Basin, in M.I., Al-Husseini, ed., Geo '94--Papers from the Middle East Petroleum Geoscience Conference, Bahrain, p. 203-213.

Brannan, J. and Flanagan, S.F., 1998, Development of the Ghaba Salt Basin, Block 3, Oman: GeoArabia, v. 3, p. 74.

Brennan, P., 1985, Middle Cretaceous carbonate reservoirs, Fahud field and northwestern Oman: Discussion: American Association Petroleum Geologist Bulletin, v. 69, p. 809818.

Droste, H.H.J., 1997, Stratigraphy of the Lower Paleozoic Haima Supergroup of Oman: GeoArabia, v. 2, p. 419-492.

Edgell, H.S., 1991, Proterzoic salt basins of the Persian Gulf area and their role in hydrocarbon generation: Precambrian Research, v. 54, p. 1-14.

Faulkner, T., 1998, North Oman Salt Flank Diapir Exploration: GeoArabia, v. 3, p. 93.

Frost, S.H., Bliefnick, and Harris, P.M., 1983, Deposition and porosity evolution of a Lower Cretaceous rudist buildups, Shuaiba Formation of eastern Arabian Peninsula, in Harris, P.M., ed., Carbonate Buildups: Society Economic Paleontologists Mineralogists Core Workshop 4, p. 381-410.

Gorin, G.E., Racz, L.G., and Walter, M.R., 1982, Late Precambrian-Cambrian sediments of Huqf Group, Sultanate of Oman: American Association Petroleum Geologist Bulletin, v. 66, p. 2609-2627

Graham, G., and Naylor, M., 1996, Exploration: Past and present: Exporation in Oman -New Ideas from Old Basins, Petroleum Development Oman, p. 3-12.

Grantham, P.J., Lijmbach, G.W.M., and Posthuma, J ., Hughes-Clarke, M.W., and Willink, R.J., 1988, Origin of crude oils in Oman, Journal of Petroleum Geology, v. 11, p. 61-80.

Grantham, P.J., Lijmbach, G.W.M., and Posthuma, J., 1990, Geochemistry of crude oils in Oman, in Brooks, J. (ed), Classic Petroleum Provinces, Geological Society Special Publication No. 50, p. 317-328.
Guit, F. A., Al-Lawati, M. H., and Nederlof, P.J.R., 1995, Seeking new potential in the Early-Late Permian Gahrif Play, West Central Oman, in M.I., Al-Husseini, ed., Geo '94--Papers from the Middle East Petroleum Geoscience Conference, Bahrain, pp. 447-462.

Harris, P.M., and Frost, S.H., 1984, Middle Cretaceous carbonate reservoirs, Fahud field and northwestern Oman: American Association Petroleum Geologist Bulletin, v.68, p. 649-658.

Hartstra, R.,and Graham, G., 1996, The Athel silicilyte play -- Status and scope: : Exporation in Oman -- New Ideas from Old Basins, Petroleum Development Oman, p.78-86.

Heward, A.P., 1990, Salt removal and sedimentation in southern Oman, in Robertson, A.H.F., Searle, M.P., and Ries, A.C., eds., The Geology and Tectonics of the Oman Region: Geological Society of London Special Publication 49, p. 637-651.

Hughes-Clarke, M.W., 1988, Stratigraphy and rock unit nomenclature in the oil-producing area of interior Oman: Journal of Petroleum Geology, v.11, pp 5-60.

Husseini, M.I. and Husseini, S.I., 1990, Origin of the Infracambrian Salt Basins fo the Middle East, in Brooks, J. (ed), Classic Petroleum Provinces, Geological Society of London Special Publication No. 50, pp 279-292.

Klett, T.R, Ahlbrandt, T.S., Schmoker, J.W., and Dolton, G.L., 1997, Ranking of the World's oil and gas provinces by known petroleum volumes: U.S. Geological Survey Open-File Report 97-463, One CD-ROM.

Klomp, U.C., 1986, The chemical structure of a pronounced series of iso-alkanes in South Oman crudes: Organic Geochemistry, v. 10, p. 807-814.

Knott, D.J., 1998, Oman prepares for oil expansion and gas production for LNG export: Oil and Gas Journal, v. 96, p. 29-34.

Lake, Stuart, 1996, Hydrocarbon plays of Oman: Exporation in Oman -- New Ideas from Old Basins, Petroleum Development Oman, p. 27-39.

Levell, B.K., Braakman, J.H., and Rutten, K.W., 1988, Oil-bearing sediments of the Gondwana glaciation in Oman: American 
Association Petroleum Geologist Bulletin, v. 72, p. 775-796.

Litsey, L.R., Macbride, W.L., Jr., Al Hinai, K.M., and Dimukes, N.B., 1983, Shuaiba reservoir geological study, Yibal field, Oman: 3rd SPE Middle East Oil Show (Bahrain), SPE 11454, P. 131-142.

Loosveld, R.J.H., Bell, A., and J.J.M. Terken, 1996, The tectonic evolution of Oman: GeoArabia, v. 1, pp 28-51.

Magoon, L.B., and Dow, W.G., 1994, The petroleum system, in Magoon, L.B., and Dow, W.G., eds., The Petroleum System -From Source to Trap: American Association Petroleum Geologist Memoir 60, p. 3-23.

Mattes, B.W., and Conway-Morris, S., 1990, Carbonate/evaporite deposiiton in the Late Precambrian-Early Cambrian Ara Formation of southern Oman, in , A.H.F., Searle, M.P., and Ries, A.C. (eds), The Geology and Tectonics of the Oman Region, Geological Society Special Publication No. 49, pp 617636.

Murris, R.J., 1980, Middle East, stratigraphic evolution and oil habitat: American Association Petroleum Geologist Bulletin, v. 64, p. 597-617.

Nederlof, P.J.R., Gijsen, M.A., and Doyle, M.A., 1995, Application of reservoir geometry to field appraisal, in M.I., Al-Husseini, ed., Geo '94--Papers from the Middle East Petroleum Geoscience Conference, Bahrain, p. 709-722.

Oil and Gas Journal, 1997, Canadian firms pressing Oman exploration: v. 95, p. 32.

Onderwaater, J., Wams, J., and Potters, H., 1996, Geophysics in Oman: GeoArabia, v.1, p. 299323.

Petroconsultants, 1996, Petroleum exploration and production database, Houston, Texas, Petroconsultants, Inc. [database available from Petroconsultants, Inc., P.O. Box 740619, Houston, Texas 77274-0619].

Petroleum Economist, 1998, Oman -- an integrated oil nation: London, v. 65 , p. $25-$ 33.

Pollastro, R.M., Karshbaum, A.S., and Viger, R.J., 1998, Map showing geology, oil and gas fields, and geologic provinces of the Arabian Peninsula: U.S. Geological Survey Open-File Report 97-470B, One CD-ROM.
Richard, P.D., Nederlof, P.J.R., Terken, J.J.M., and Al-Ruwehy, N., 1998a, Integrated Haushi hydrocarbon study in North Oman: GeoArabia, v. 3., p. 146-147.

Richard, P.D., Nederlof, P.J.R., Terken, J.J.M., and Al-Ruwehy, N., 1998b, Generation and retention of hydrocarbons in the Haushi Play, North Oman: GeoArabia, v. 3., p. 493506.

Robertson, A.H.F, Searle, M.P., and Ries, A.C. (eds), 1990, The Geology and Tectonics of the Oman Region: Geological Society London Special Publication 49.

Schmidt, D.L., Hadley, D.G., and Stoesser, D.B., 1979, Late Proterozoic crustal history of the Arabian Shield, southern Najd province, Kingdom of Saudi Arabia: Evolution and Mineralization of the Arabian-Nubian Shield, Institute of Applied Geology, Jeddah, v. 2, p. 41-58.

Sharief, F.A.M., 1982, Lithofacies distribution of the Permian-Triassic rocks of the Middle East: Journal of Petroleum Geology, v. 5, p. 203-206.

Sykes and Abu Risheh, 1989, Exploration of deep Paleozoic and Precambrian plays in the Sultanate of Oman, in Country reports and case studies on deep formations in the Arab countries--Hyrocarbon potential and exproation techniques; OAPEC/ADNOC Proceedings, Abu Dhabi, p. E71-E113.

Terken, J.M.J., 1998, The Natih petroleum system (abst.) : GeoArabia, v. 3, p. 163.

Terken, J.M.J. (in press) The Natih petroleum system: GeoArabia.

U.S. Energy Information Administration, 1998, Country Analysis Briefs -- Oman: URL: http:/www.eia.doe.gov/emeu/cabs/oman. html, January 14, 1998, 8 pp.

Vail, P.R., Audemard, F., Bowman, S.A., Eisner, P.N., and Perez-Cruz, C., 1991, The stratigraphic signature of tectonics, eustasy, and sedimentology -- An overview, in Einsele, G., Ricken, W., and Seilacher, A., eds., Cycles and Events in Stratigraphy, Springer-Verlag, Berlin Heidelberg, p. 617659.

van Buchem, F.S.P.. Razin, P., Homewood, P.W., and others, 1996, High resolution sequence stratigraphy of the Natih Formation (Cenomanian-Turonian) in Northern Oman: 
Distribution of source rocks and reservoir facies: GeoArabia, v. 1, p.65-91.

van Buchem, F.S.P., Razin, P., Huc, A.Y., Pradier, B., Homewood, P.W., and Oterdoom, H.W., 1998, The stratigraphic creation of intrashelf basins: Examples from the Cenomanian/Turonian (Natih Formation) in north Oman: GeoArabia, v. 3, p.169-170.

Vahrenkamp, V., and Grotsch, J., 1995, 3-D architecture model of a Lower Cretaceous carbonate reservoir, Al Huwaisah field, Sultanate of Oman, in M.I., Al-Husseini, ed., Geo '94--Papers from the Middle East Petroleum Geoscience Conference, Bahrain, p. 901-915.

Visser, W., 1991, Burial and thermal history of Proterozoic source rocks in Oman: Precambrian Research, v. 54, p. 15-36.

Whyte, S.J., 1995, Natih Field, Oman, in M.I., AlHusseini, ed., Geo '94--Papers from the Middle East Petroleum Geoscience Conference, Bahrain, v. 2, p. 917-925.

\section{List of Figures}

Figure 1. -- Map showing U.S. Geological Survey (USGS) Province boundaries, province names and numbers, location of burial histories, and oil and gas field centerpoints (Petroconsultants, 1996) in Central and North Oman. Scale: 1:3,600,000. [Burial history location for: A, figure 12 near Saih Rawl field; B, figure 13 near Barik field; C, figure 15 near Yibal field; $\mathbf{D}$, figure 15 near Jaleel field; E, figure 18 in Omani foredeep; F, figure 19 near Anaima-1 well].

Figure 2. -- Map showing salt basins, structural elements, and major oil and gas fields of Oman. Modified from Loosveld and others (1996).

Figure 3. -- Generalized northwest-southeast cross-section across northern Oman and the Ghaba Salt Basin, Central Oman Platform (Makarem High), and Fahud Salt Basin showing major oil and gas fields, proven occurrences, and potential traps (see figure 1 for location of line of section). See figure 5 for ages of units. Modified from Droste (1997).
Figure 4. -- Generalized east-west cross-section across central Ghaba Salt Basin showing major oil and gas fields, proven occurrences, and potential traps (see figure 1 for location of line of section). See figure 5 for ages of units. Modified from Droste (1997).

Figure 5. -- Stratigraphic section of Oman showing source rocks and producing reservoirs for Ghaba and Fahud Salt Basins. Modified from Loosveld and others (1996) and Droste (1997).

Figure 6. -- Geographic distribution of oil types found in Oman and appoximate ' $Q$ ' oil migration fairway. Data compiled from numerous sources including Grantham and others (1988), Sykes and Abu Risheh (1989), Guit and others, (1995), Lake (1996), AlRuwehy and Frewin (1998), Richard and others (1998), and Terken (1998, in press). Not all oils shown here are discussed in this report. Solid green dots indicate oil fields; solid red dots indicate gas fields.

Figure 7. -- Various populations for Oman oil types identified from cross plot of total carbon isotope versus $C_{27}$ sterane percent. Modified from Terken (in press).

Figure 8. -- Petroleum system events chart for North Oman Huqf/'Q' -- Haushi(!) Total Petroleum System (201401), Ghaba Salt Basin Province (2014), Oman.

Figure 9. -- Petroleum system events chart for North Oman Huqf -- Shu'aiba(!) Total Petroleum System (201601), Fahud Salt Basin Province (2016), Oman.

Figure 10. -- Petroleum system events chart for Middle Cretaceous Natih(!) Total Petroleum System (201602), Fahud Salt Basin Province (2016), Oman.

Figure 11. -- Map showing Ghaba Salt Basin Province (2014), North Oman Huqf/'Q' -Haushi(!) Total Petroleum System (201401), and Ghaba-Makarem Combined Structural Assessment Unit (20140101). Oil and gas field centerpoints (Petro-consultants, 1996) and boundaries for pod of active source rock and minimum petroleum system are also shown. Scale $=1: 3,600,000$.

Figure 12. -- Burial-history diagram, vitrinite reflectance equivalant (VRE), and stages of hydrocarbon (HC) generation for Huqf source rocks from unidentified well in 
vicinity of Saih Rawl field, Ghaba Salt Basin Province, Oman. Modified from Visser (1991).

Figure 13. -- Burial-history diagram for deep-gas reservoirs, Barik Sandstone Member, showing temperatures and stages of oil and gas charge from Huqf intra-salt source rocks, Barik field, Ghaba Salt Basin. Modified from Borgomano and others (1996).

Figure 14. -- Map showing Fahud Salt Basin Province (2016), North Oman Huqf -Shu'aiba(!) Total Petroleum System (201601), and Fahud-Huqf Combined Structural Assessment Unit (21060101). Oil and gas field centerpoints (Petro-consultants, 1996) and boundaries for pod of active source rock and minimum petroleum system are also shown. Scale $=1: 2,750,000$.

Figure 15. -- Burial-history diagram, vitrinite reflectance equivalance (VRE), and stages of hydrocarbon (HC) generation for Huqf source rocks from unidentified well in vicinity of Yibal field, Fahud Salt Basin Province, Oman. Modified from Visser (1991).

Figure 16. -- Burial-history diagram for deep-gas reservoirs, Upper Cambrian-Lower Ordovician Barik Sandstone Member, showing temperatures and stages of oil and gas charge from Huqf post-salt source rocks, Jaleel field, Fahud Salt Basin. Modified from Borgomano and others (1996).
Figure 17. -- Map showing Fahud Salt Basin Province (2016), North Oman Middle Cretaceous Natih(!) Total Petroleum System (201602), and Natih/Fiqa StructuralStratigraphic Assessment Unit (20160201). Oil and gas field centerpoints (Petroconsultants, 1996) and boundaries for pod of active source rock and minimum petroleum system also shown. Scale = 1:2,750,000.

Figure 18. -- Burial-history diagram, burial temperatures, and vitrinite reflectance equivalent (VRE) for Natih Formation source rocks in Late Cretaceous/Tertiary foredeep, Fahud Salt Basin, north Oman. Modified from Terken (1998; in press).

Figure 19. -- Burial-history diagram and major diagenetic events of Wasia Group near Anaima-1 well, Fahud Salt Basin, north Oman. Modified from Harris and Frost (1984).

\section{List of Tables}

Table 1. -- Characteristics of oils and source rocks of Ghaba and Fahud Salt Basin Provinces, Oman.

Table 2. -- Allocation of oil and as fields to petroleum systems and assessment units of the Ghaba and Fahud Salt Basin Provinces. 
Table 1. -- Common characteristics of source rocks and oils of Ghaba and Fahud Salt Basin Provinces, north-central Oman. (TOC, total organic carbon in weight percent: OMt, organic-matter type; \%S, percent sulfur in oil; $\mathrm{X}$-c, presence/absence of $\mathrm{X}$-branched compounds)

\begin{tabular}{|c|c|c|c|c|c|c|}
\hline $\begin{array}{c}\text { Source rock/ } \\
\text { oil type }\end{array}$ & OMt & $\begin{array}{l}\text { TOC } \\
(\%)\end{array}$ & $\partial^{13} \mathrm{C}(\% 0)$ & $\begin{array}{l}\text { Sterane } \% \\
\left(\mathrm{C}_{27}, \mathrm{C}_{28}, \mathrm{C}_{29}\right)\end{array}$ & API & $\% \mathrm{~S}$ \\
\hline North Oman Huqf & $\mathrm{I} / \mathrm{II}$ & 3 & -33 to -35 & $20,20,60$ & $25-45$ & $1.0-2.0$ \\
\hline Huqf ' $Q$ ' & $\mathrm{I} / \mathrm{II}$ & $?$ & -30 to -31 & $63,22,15$ & $40-50$ & $0.1-0.4$ \\
\hline Natih & $\mathrm{I} / \mathrm{II}$ & 5 & -27 & $34,38,28$ & $31-32^{\circ}$ & 1.5 \\
\hline
\end{tabular}


Table 2. -- Allocation of known oil and gas fields to Total Petroleum Systems and Assessment Units of the Ghaba and Fahud Salt Basin Provinces, Oman. Gas fields indicated in bold type.

201401 North O man Huqf/'Q' -- Haushi(!) Total Petroleum System

20140101 Ghaba-M akarem Combined Structural A ssessment U nit

$\begin{array}{lllll}\text { Abber 1 } & \text { Burhaan West } & \text { Jerian 1 } & \text { Nafoorah 1 } & \text { Saih Rawl } \\ \text { Alam } & \text { Burhaan North } & \text { Jebel Madar } & \text { Nahda 1 } & \text { Safwan 2 } \\ \text { Al Ghubar } & \text { Burhaan South } & \text { Katheer 1 } & \text { Qarat Al Milh } & \text { Sayyala } \\ \text { Anbar 1 } & \text { Farha South } & \text { Mabrouk } & \text { Qarat Al Milh 1 } & \text { Shaheer 1 } \\ \text { Anzuaz } & \text { Fayyadh } & \text { Mafraq 3 } & \text { Qarn Alam } & \text { Suwaihat } \\ \text { Asfoor 2 } & \text { Ghaba East } & \text { Mahfil 1 } & \text { Rajaa } & \text { Tawf Dahm 1 } \\ \text { Bahaa 1 } & \text { Ghufos } & \text { Mahjoub 2S1 } & \text { Ramlat Rawl } & \text { Wafra } \\ \text { Bahja } & \text { Habur } & \text { Malih 1 } & \text { Rasafah 1 } & \text { Zareef } \\ \text { Baqlah 1 } & \text { Hadiyah 1 } & \text { Maqtaa } & \text { Risalah 1 } & \text { Zualiyah } \\ \text { Barakat 2 } & \text { Hasirah } & \text { Mazeed 1 } & \text { Sadad } & \\ \text { Barik } & \text { Hawqa 1 } & \text { Misfar 1 } & \text { Saih Nihayda } & \\ \text { Barik North } & \text { Hijab 1 } & \text { Mussalim } & \text { Saih Nihayda SE } & \end{array}$

\section{North 0 man Huqf -- Shu'aiba(!) Total Petroleum System}

20160101 Fahud-H uqf Combined Structural A ssessment U nit

$\begin{array}{lllll}\text { Al Aroos } & \text { Daleel } & \text { Jaleel 1st } & \text { Maqhoul South 1 } & \text { Thumayd 1 } \\ \text { Al Barakah } & \text { Fahud West (gas) } & \text { Jebel Aswad 1 } & \text { Maradi } & \text { Wadi Latham } \\ \text { Al Barakah NE 1 } & \text { Fushaigah 1 } & \text { Khatmah 1 } & \text { Mazrouq 1 } & \text { Wadi Rafash 1X } \\ \text { Al Bashair 1 } & \text { Haban 1 } & \text { Khulad 1 } & \text { Mezoon 1 } & \text { Wadi Umayri 1 } \\ \text { Al Husain 1 } & \text { Habiba 1 } & \text { Lobnah 1 } & \text { Nadir 1 } & \text { Yibal } \\ \text { Al Huwaisah } & \text { Hafar 1 } & \text { Madiq } & \text { Natih West (gas) } & \\ \text { Al Sahwa 1 } & \text { Hareer 1 } & \text { Makarem 1 (ST2) } & \text { Salmah } & \\ \text { Bushra 1 } & \text { Ibtikar 1ST } & \text { Malih 1 } & \text { Salmah South } & \end{array}$

\section{Middle Cretaceous Natih(!) Total Petroleum System}

$20160201 \mathrm{~N}$ atih-Fiqa Structural/Stratigraphic A ssessment U nit

$\begin{array}{llll}\text { Natih } & \text { Fahud West (oil) } & \text { Shipkah } & \text { Maradi (Ladah) 2 } \\ \text { Natih West (oil) } & \text { Fahud } & \text { Suqtan 1 } & \text { Qalah 1 }\end{array}$


Figure 1.

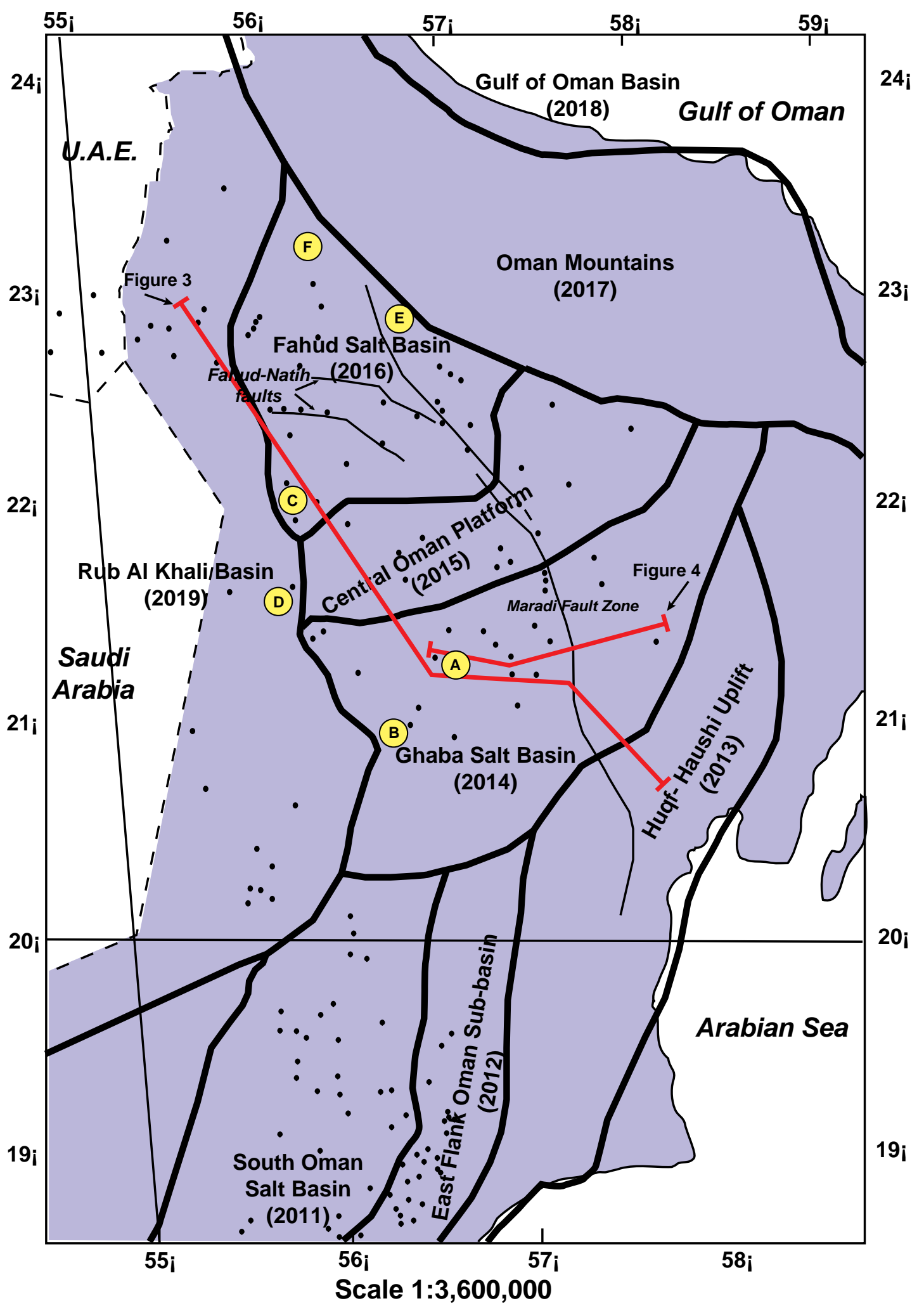

\section{Explanation}

\begin{tabular}{llll}
\hline Oman Cross Section $\quad$ Oil or Gas field centerpoint \\
USGS Province boundary
\end{tabular}


Figure 2.

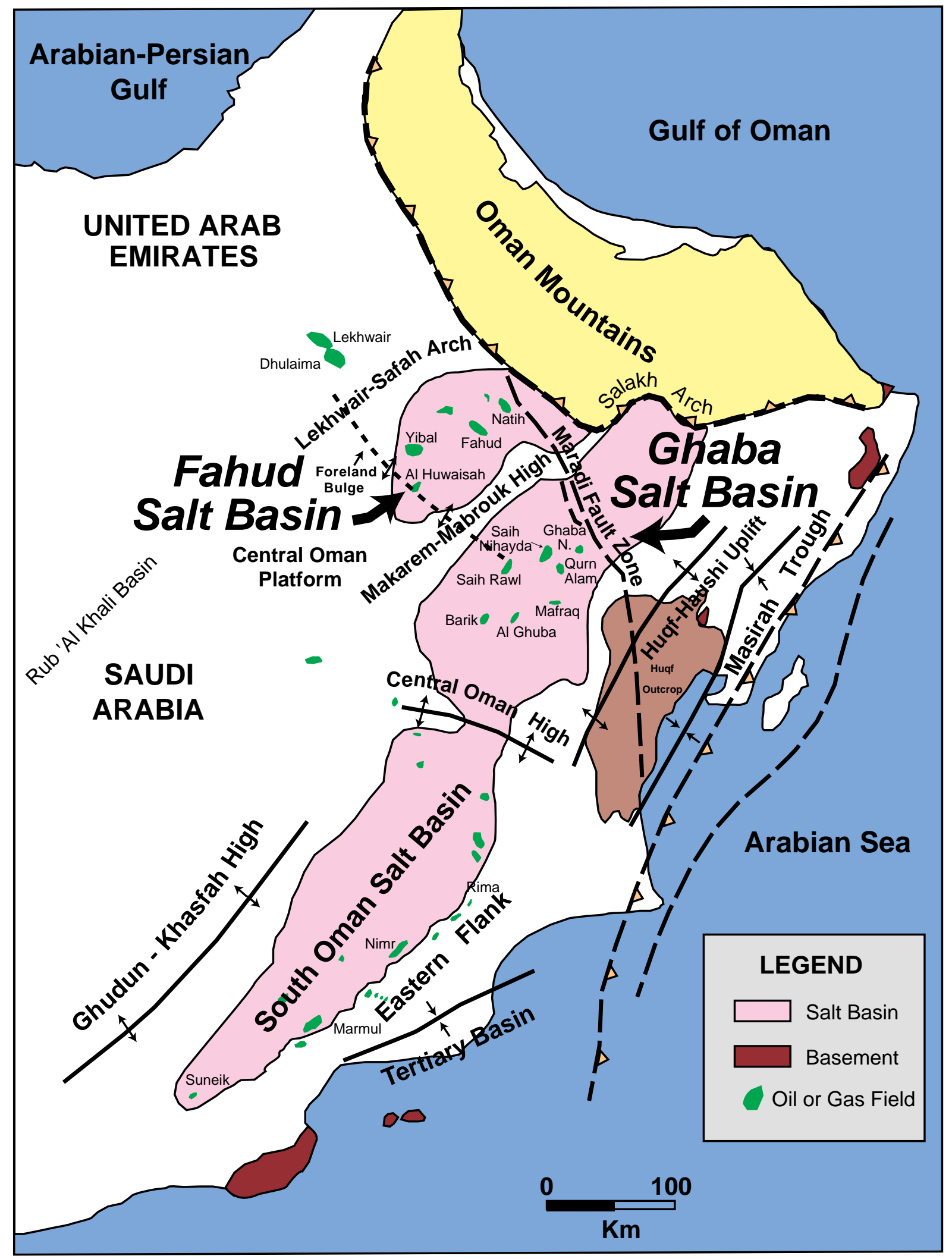

Modified from Loosveld and others (1996) 


\section{Northwest}

Figure 3.

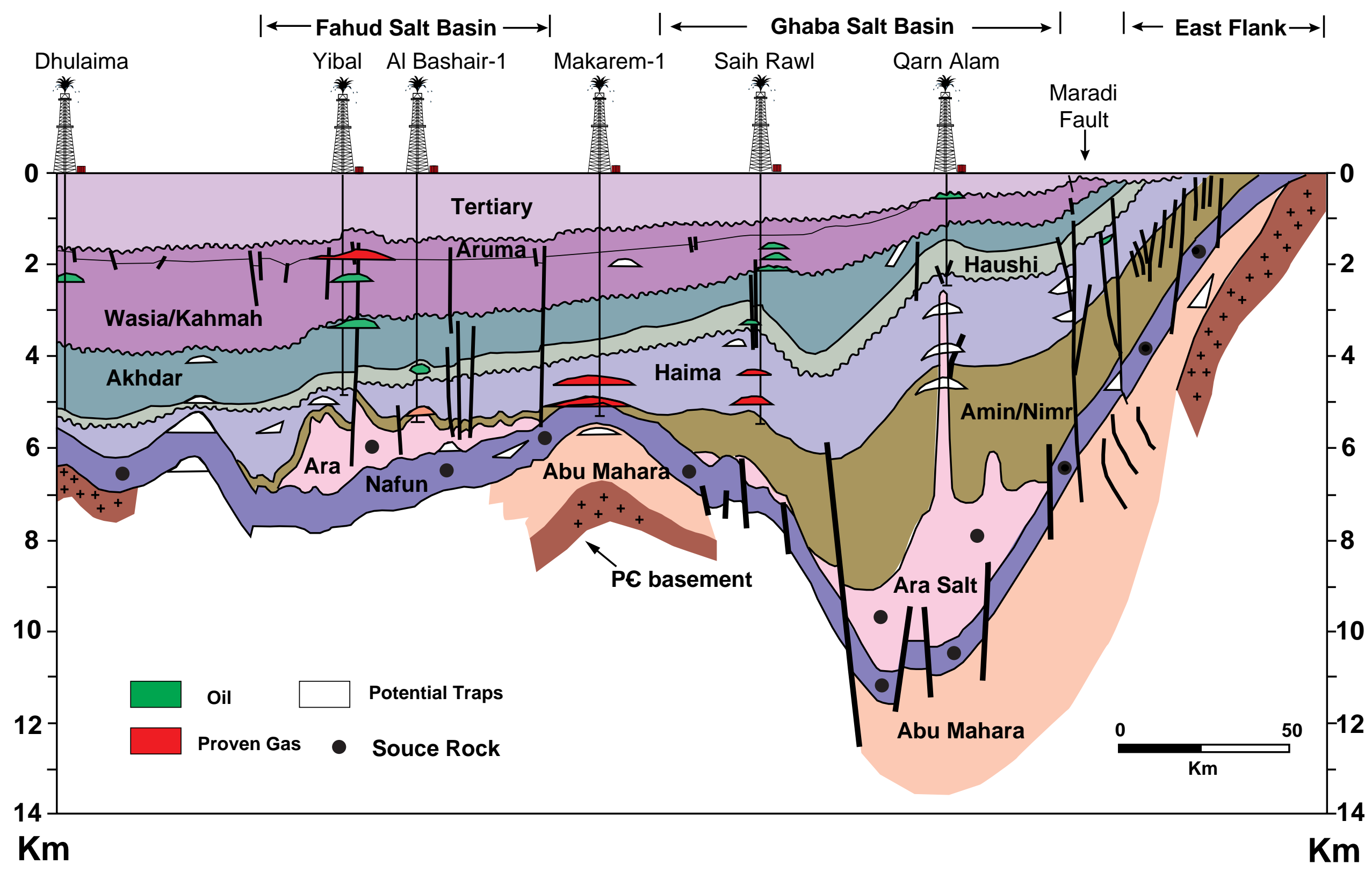

Modified from Droste (1997) 


\section{Northwest}

Figure 3.

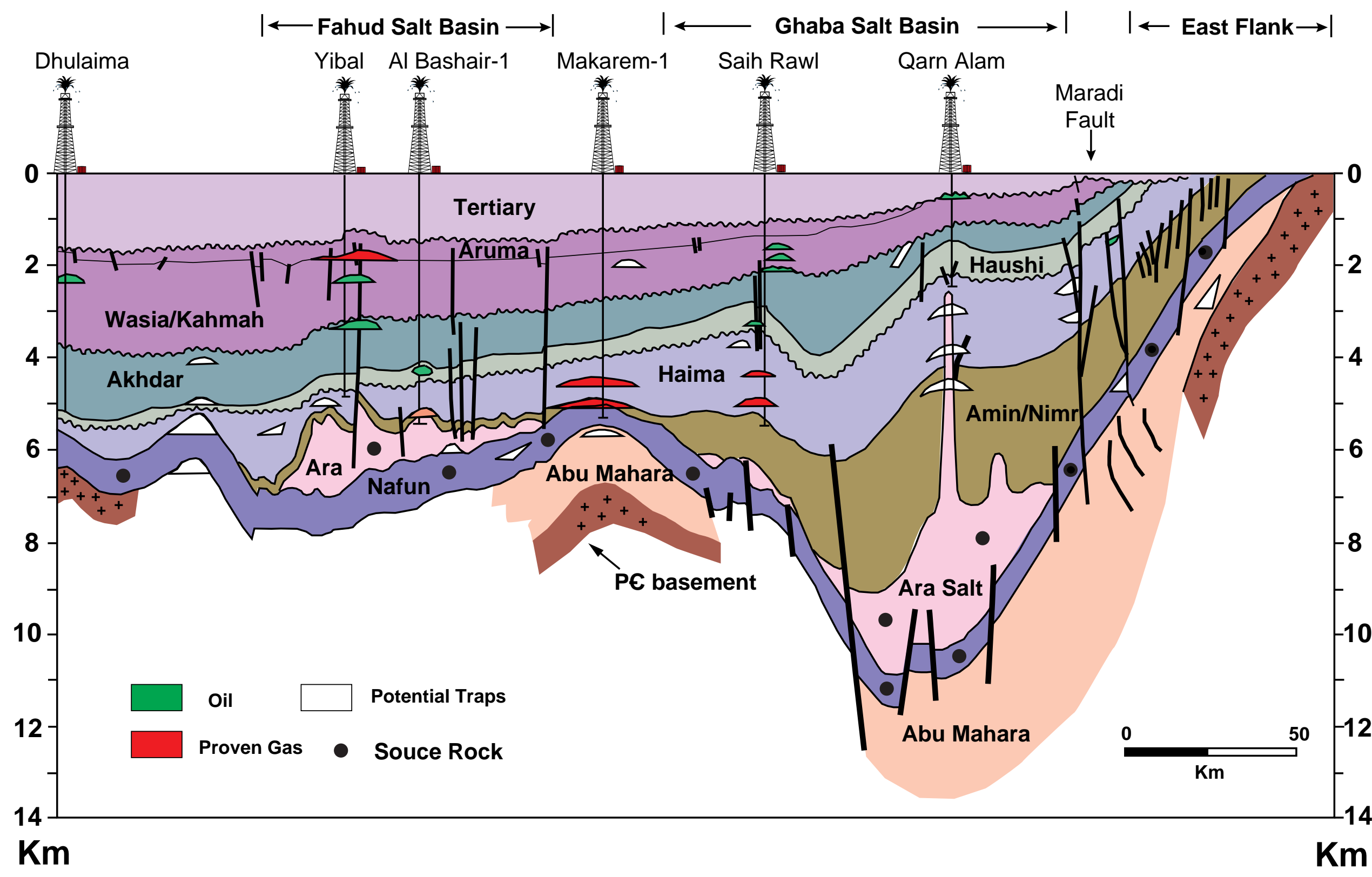

Modified from Droste (1997)

\section{Southeast}




\section{Northwest}

Figure 3.

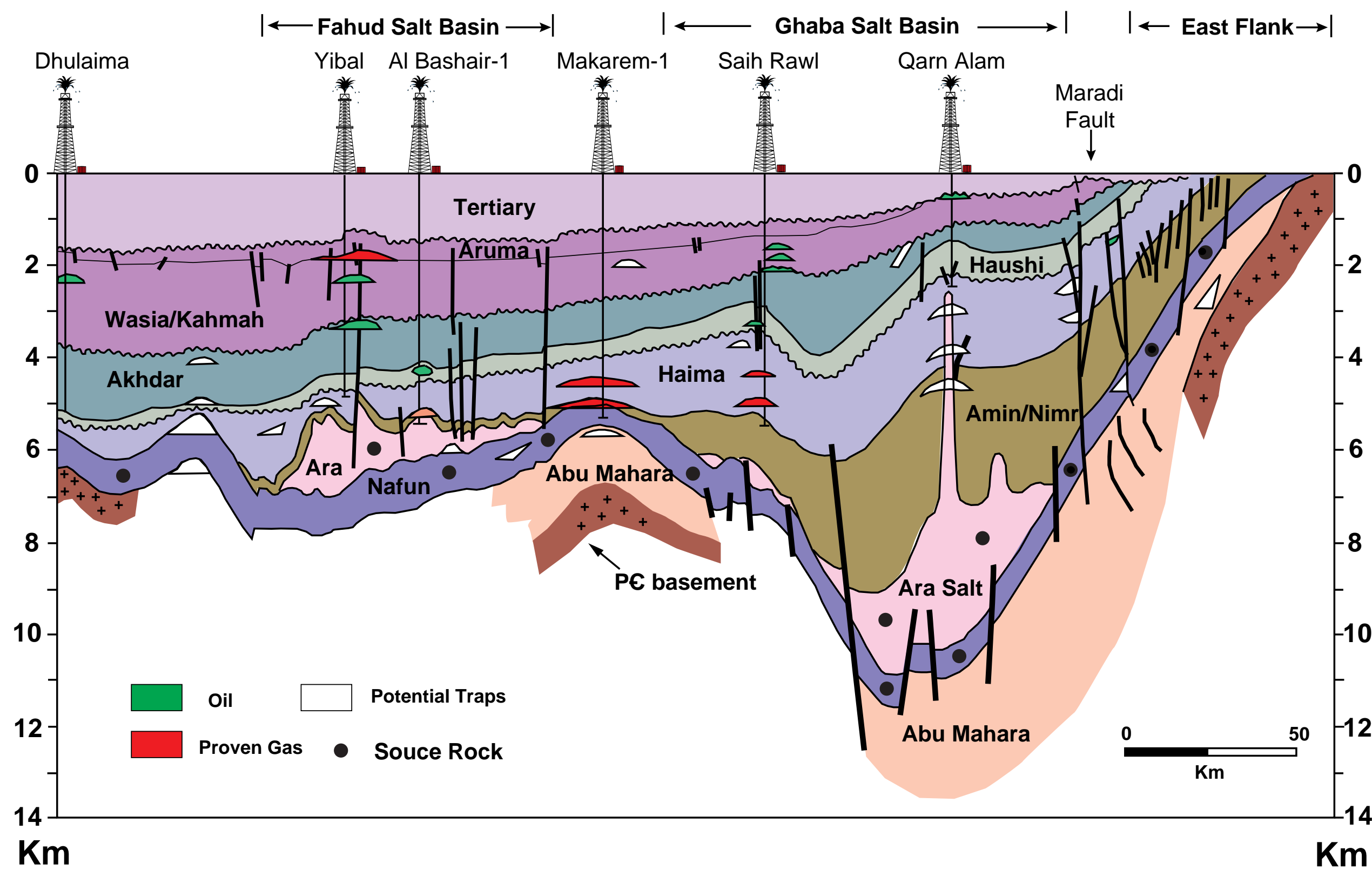

Modified from Droste (1997)

\section{Southeast}


Figure 5.

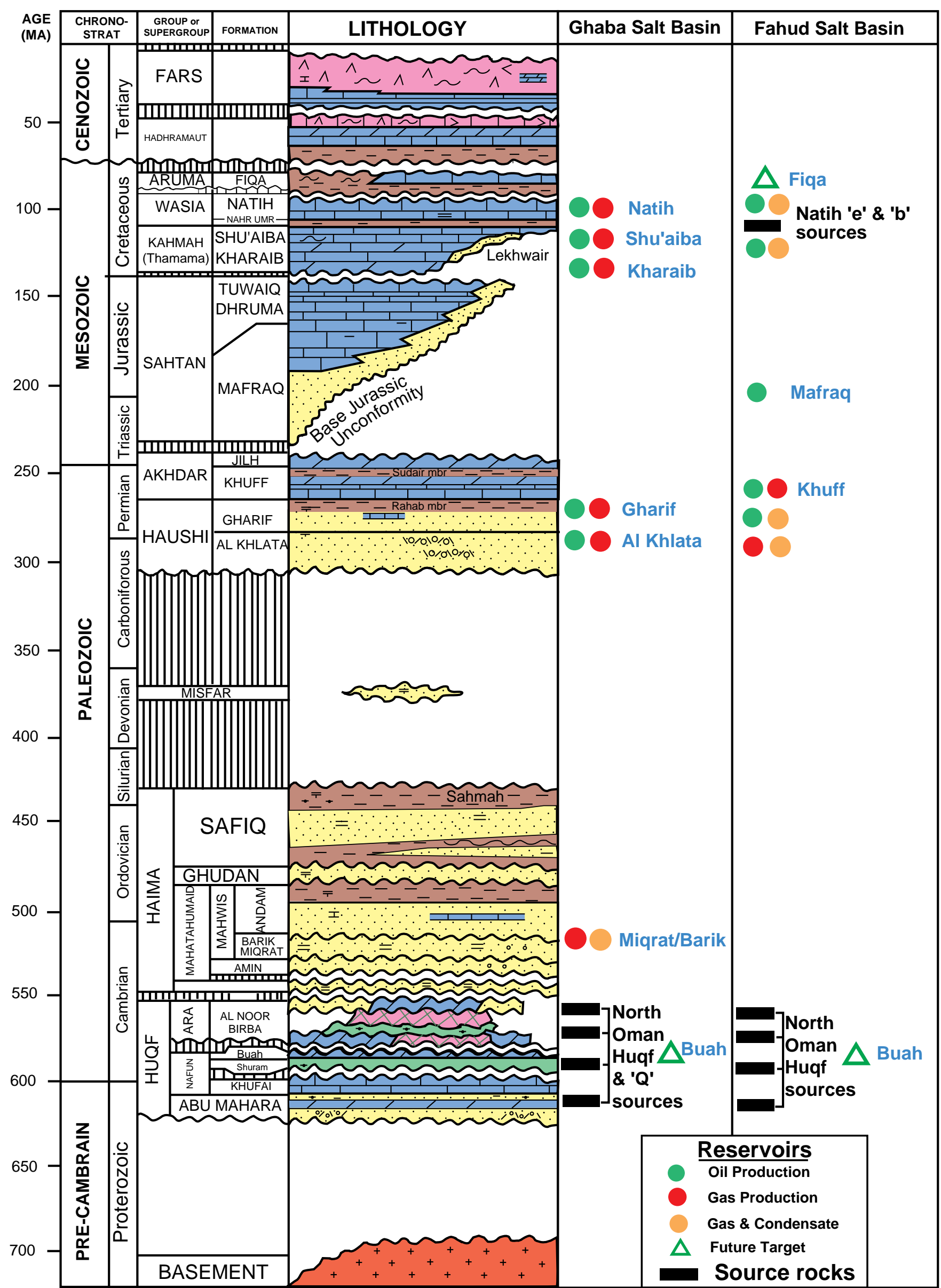


Figure 6.

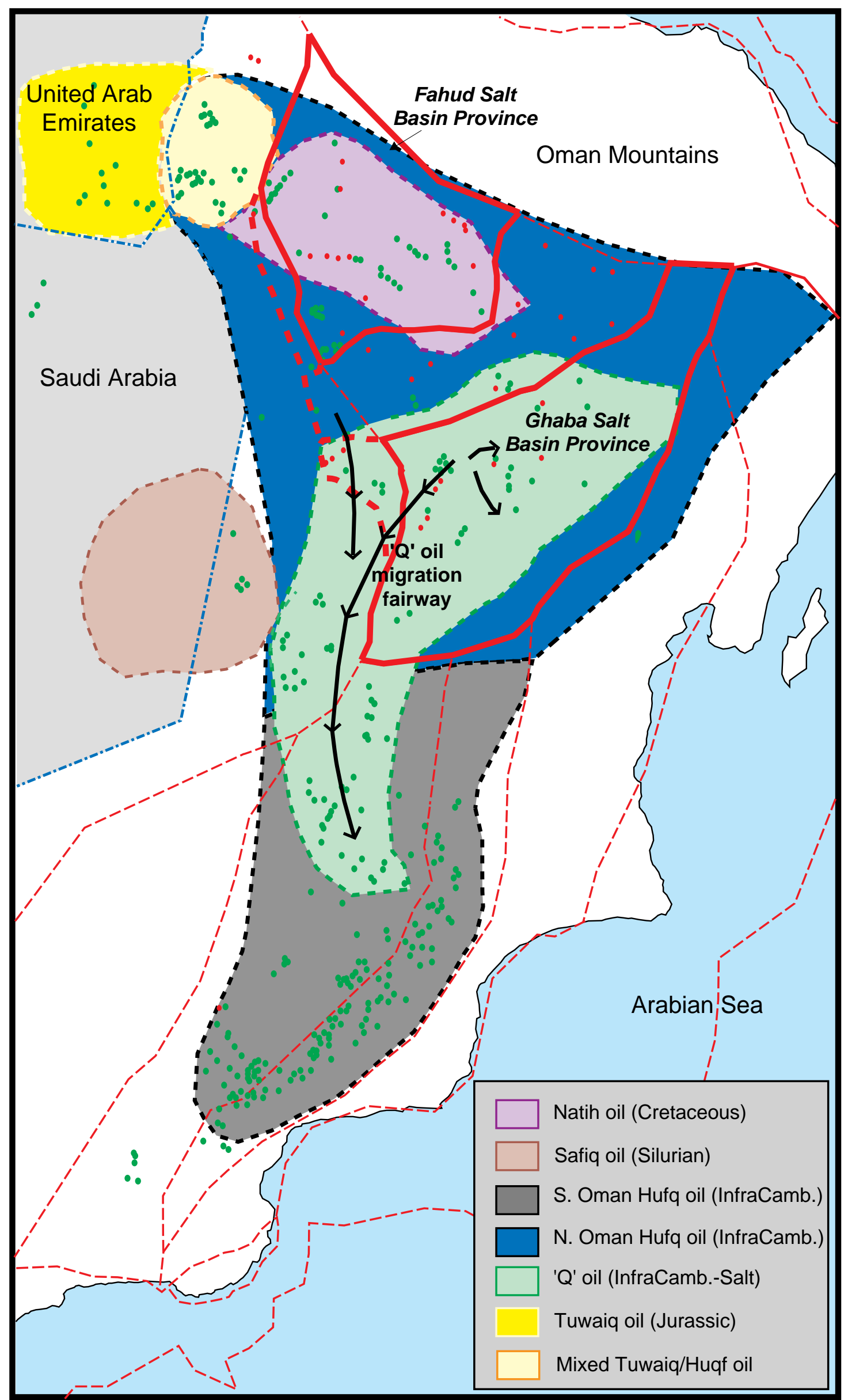


Figure 7.

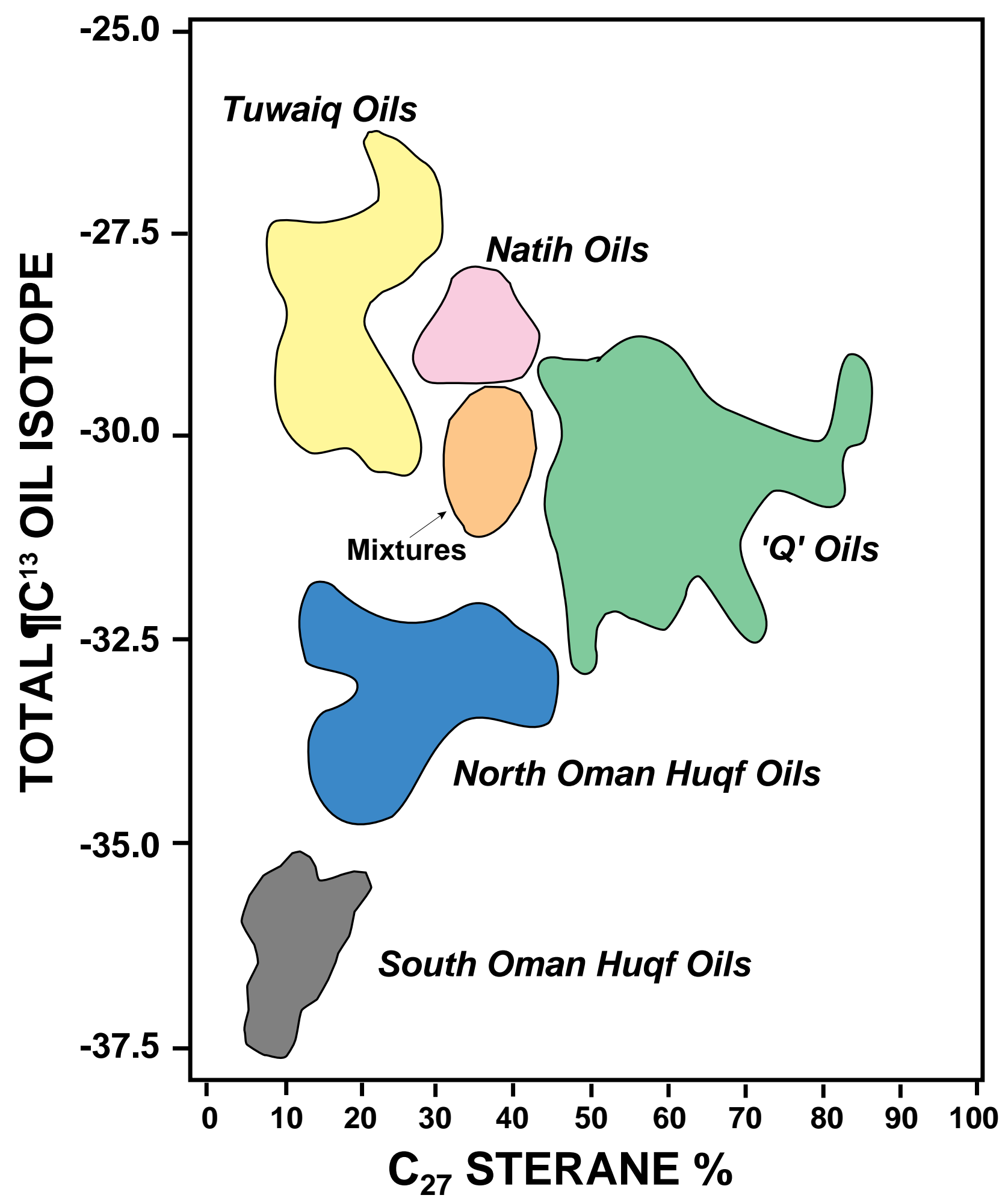

Modified from Terken (1998; in press) 
Figure 8.

\section{Total Petroleum System Events Chart}

Province Name: 2014 -- Ghaba Salt Basin TPS Name:201401 -- North Oman Huqf/'Q' - Haushi (!)

Author(s): R.M. Pollastro

Date: $\quad 8 / 11 / 98$

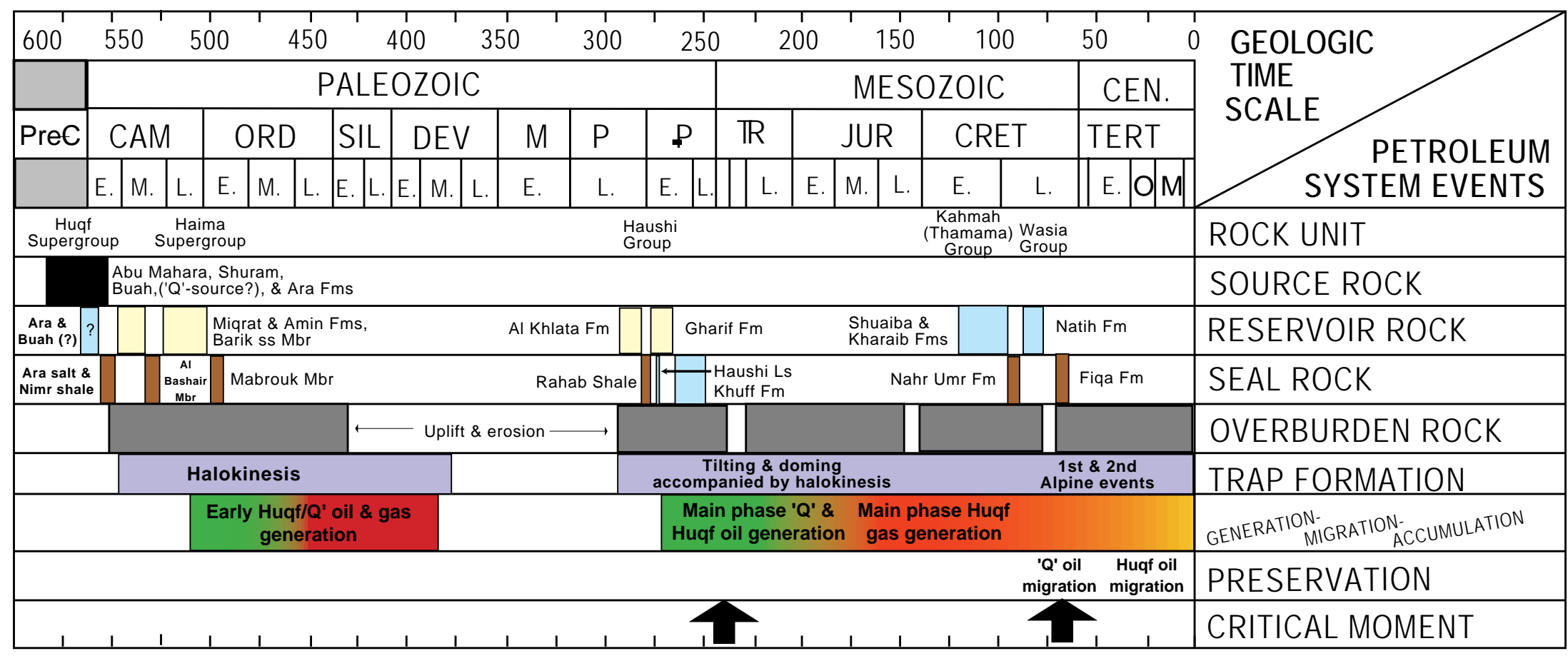


Figure 9.

\section{Total Petroleum System Events Chart}

Province Name: Fahud Salt Basin (2016) TPS Name:North Oman Huqf - Shu'aiba(!) TPS

Author(s):R.M. Pollastro

Date: $8 / 19 / 98$

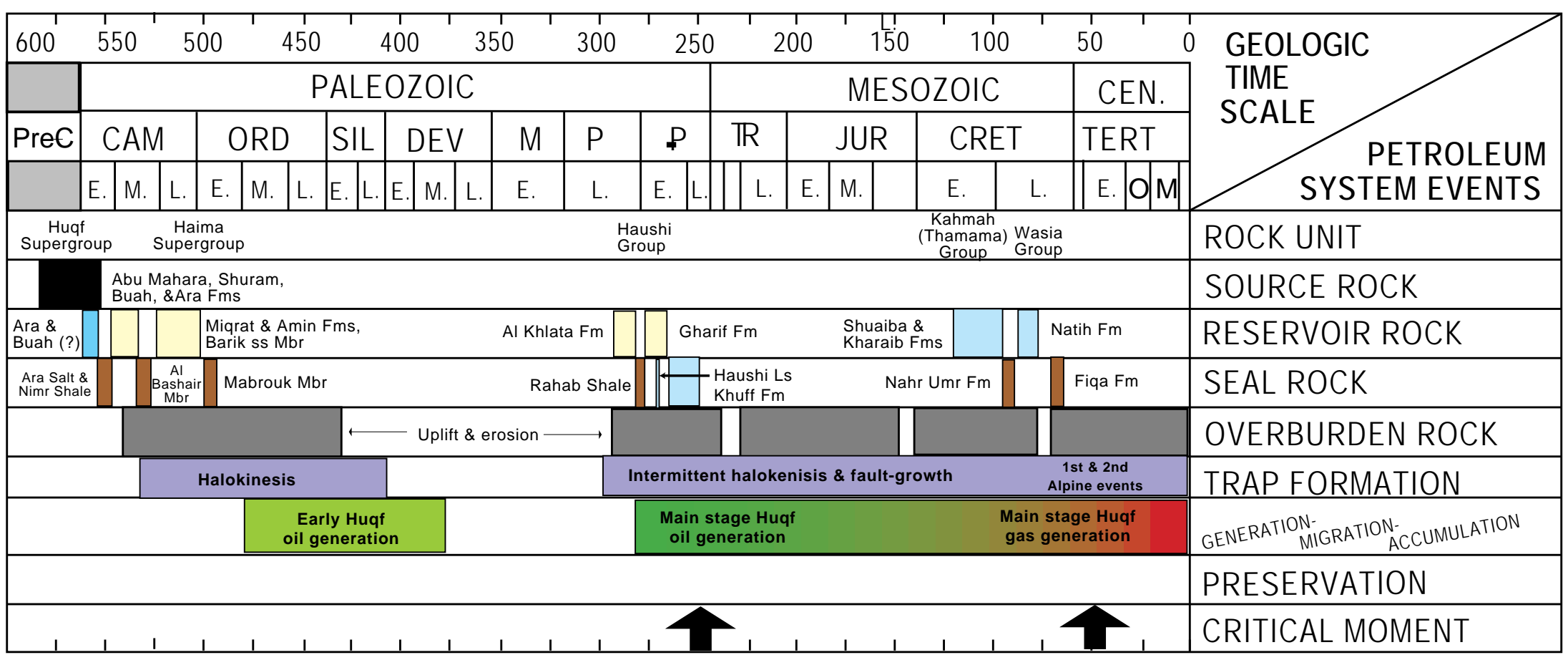


Figure 10.

\section{Total Petroleum System Events Chart}

Province Name:Fahud Salt Basin (2016) TPS Name: Natih(!) Petroleum System

Author(s): R.M. Pollastro

Date:

$8 / 11 / 98$

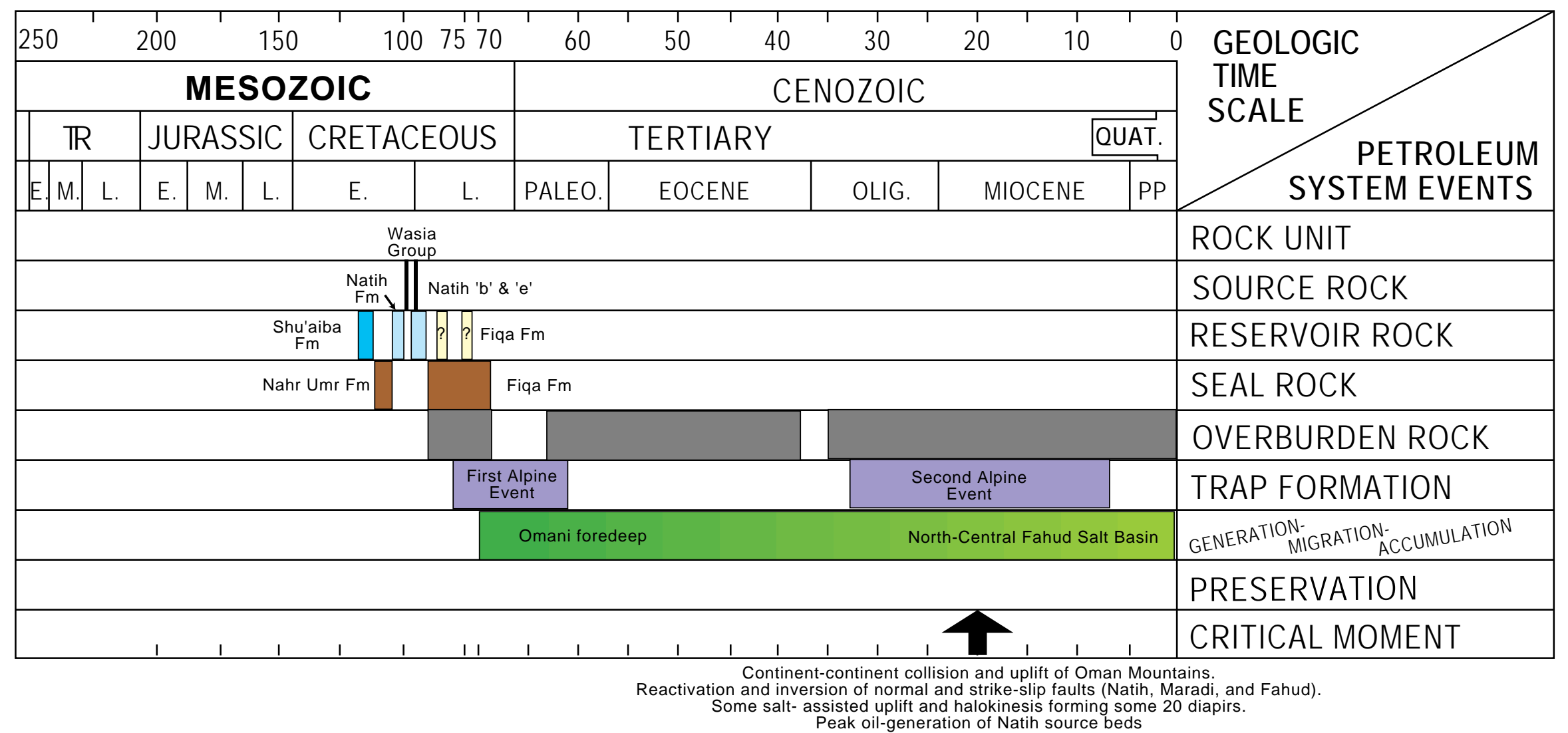


Figure 11.-- Ghaba Salt Basin Province [2014]

North Oman Huqf/'Q' - Haushi Total Petroleum System [201401]

Ghaba - Makarem Combined Structural Assessment Unit [20140101]

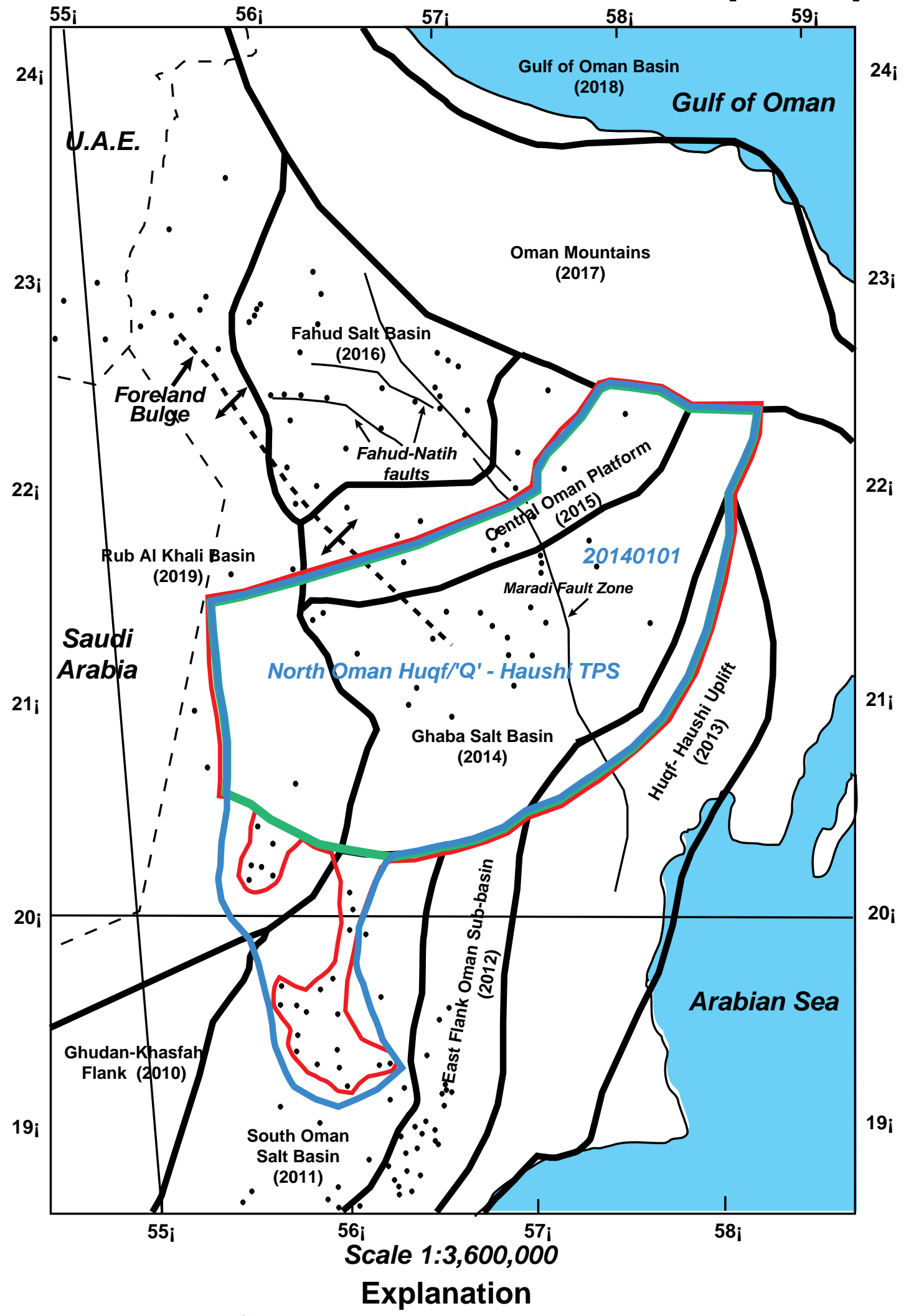

USGS Province boundary

- Oil or Gas field centerpoint
Minimum Petroleum System boundary

[201601] USGS TPS number $\begin{aligned} & \text { Pod of active } \\ & \text { source rock boundary }\end{aligned}-{ }^{\prime} \begin{gathered}\text { Country } \\ \text { boundary }\end{gathered}$ 20140101 USGS assessment unit number 
Figure 12.

Ghaba Salt Basin

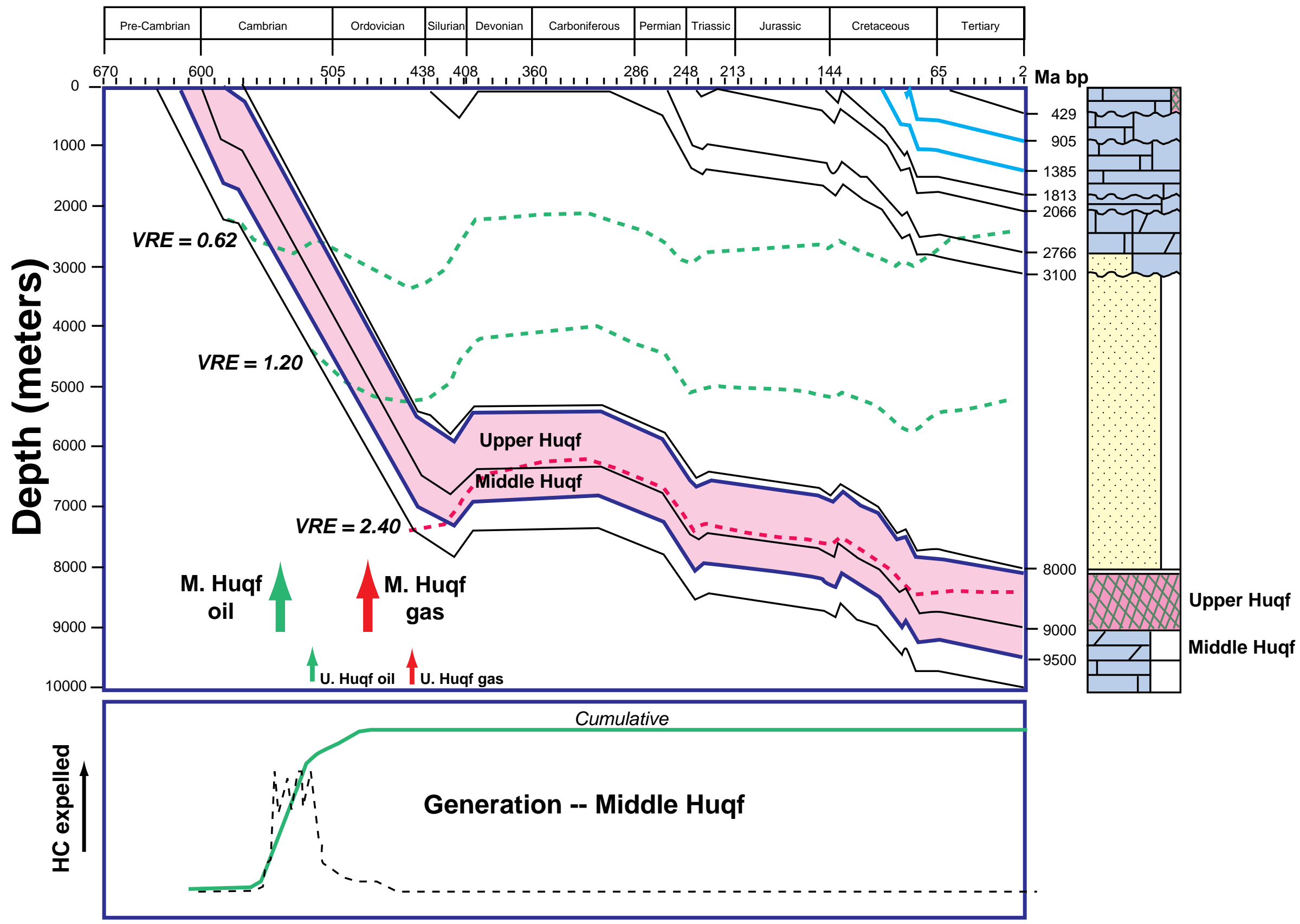

Modified from Visser (1991) 
Figure 13.

\section{Barik Field Burial History}

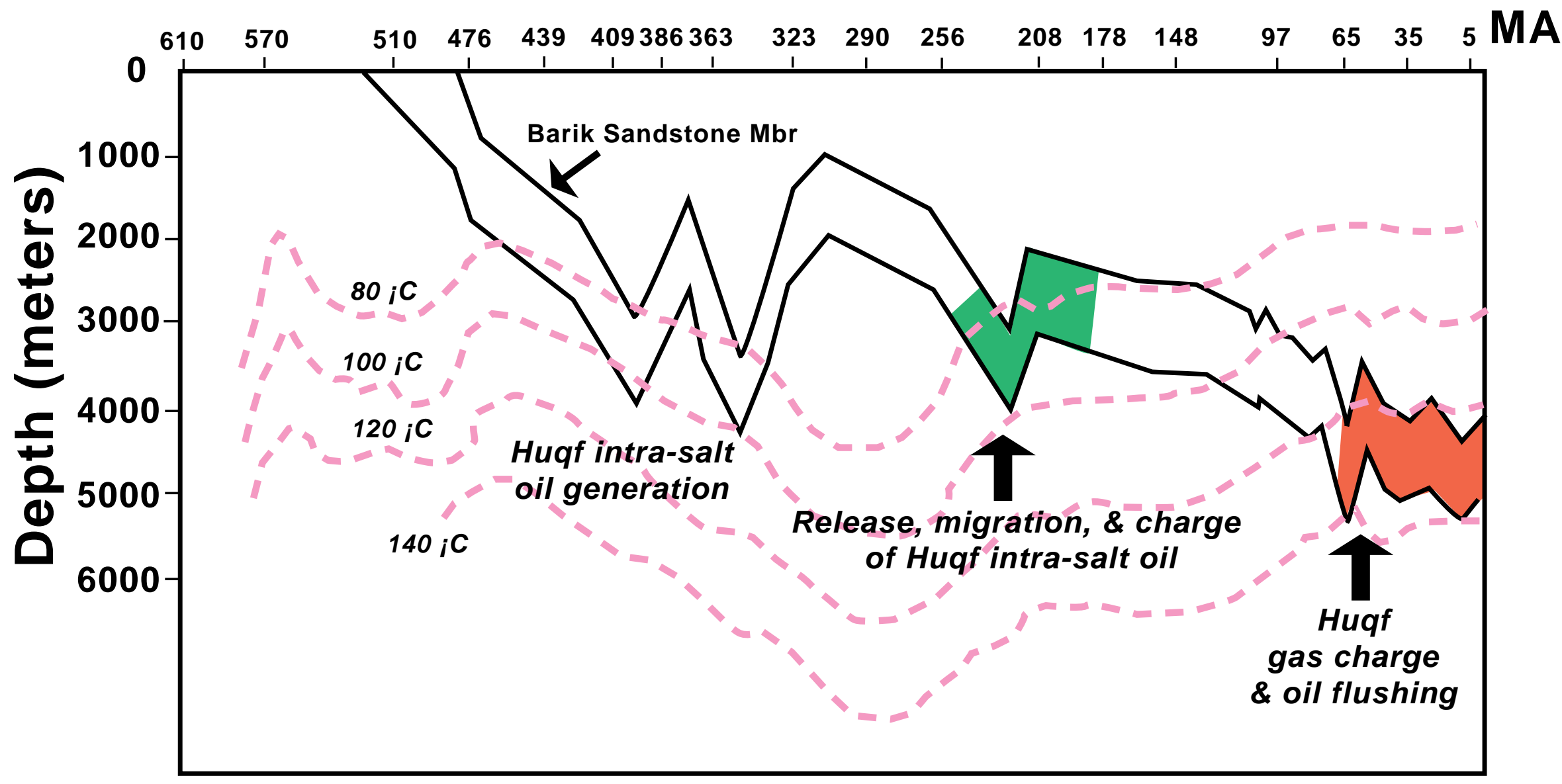

Modified from Borgomano and others (1996) 
Figure 14. -- Fahud Salt Basin Province [2016]

North Oman Huqf - Shu'aiba Total Petroleum System [201601]

Fahud - Huqf Combined Structural Assessment Unit [20160101]

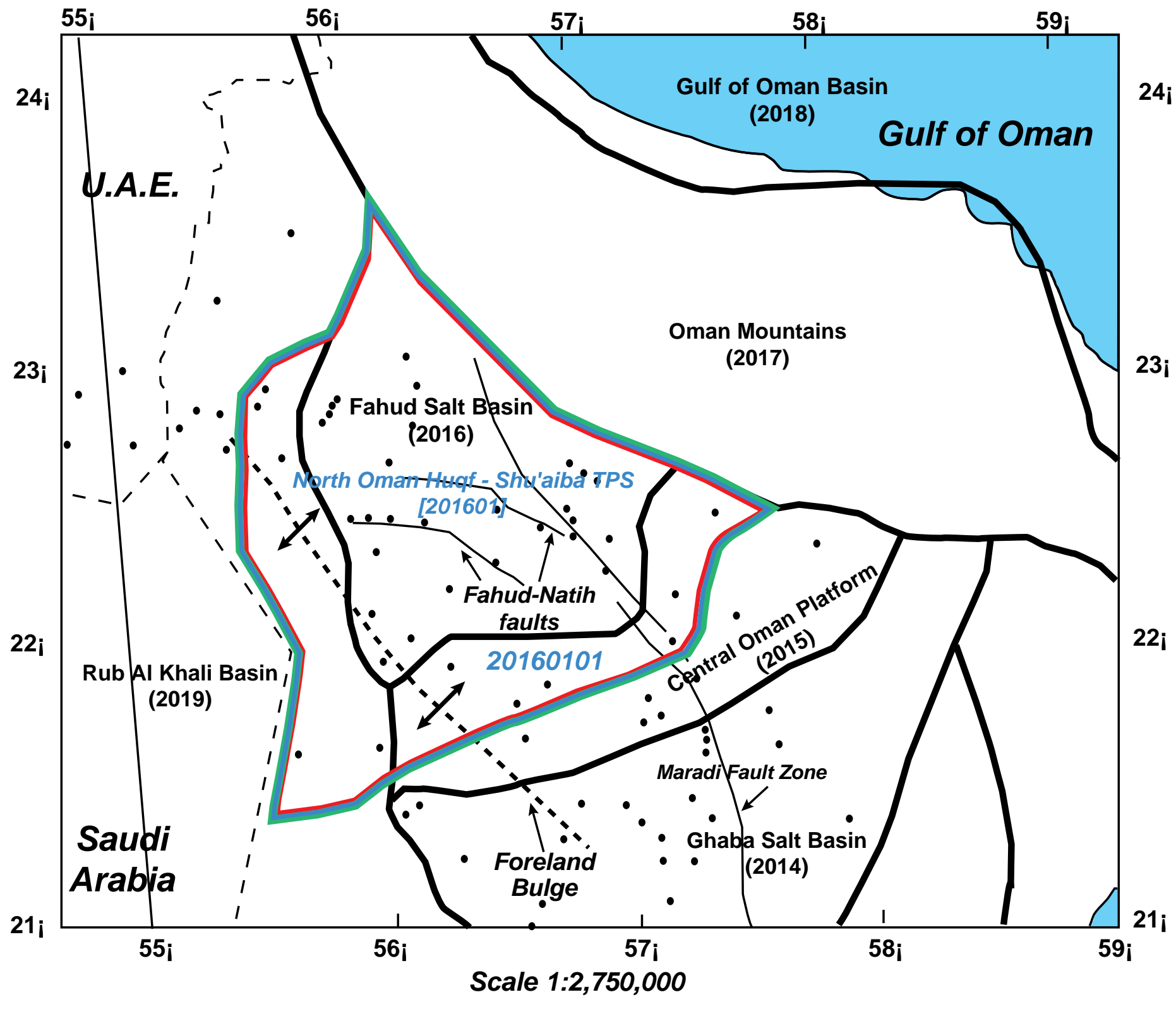

\section{Explanation}

USGS Province boundary

- Oil or Gas field centerpoint

(2016) USGS province number
Assessment unit and Total Petroleum System (TPS) boundary

Minimum Petroleum System boundary

Pod of active _ _ _ Country source rock boundary - boundary [201601] USGS TPS number 20160101 USGS assessment unit number 
Figure 15.

Fahud Salt Basin

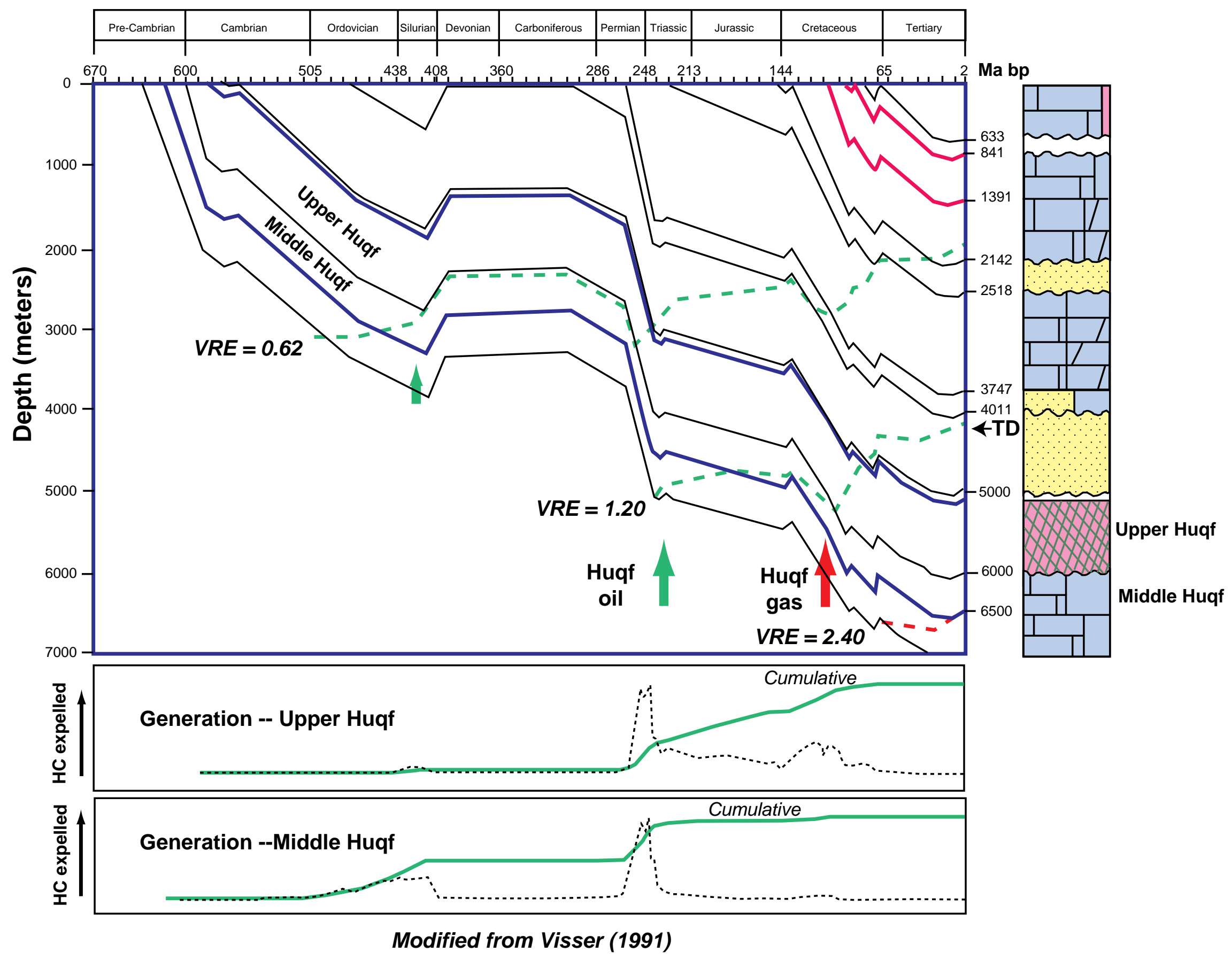


Figure 16.

\section{Jaleel Field Burial History}

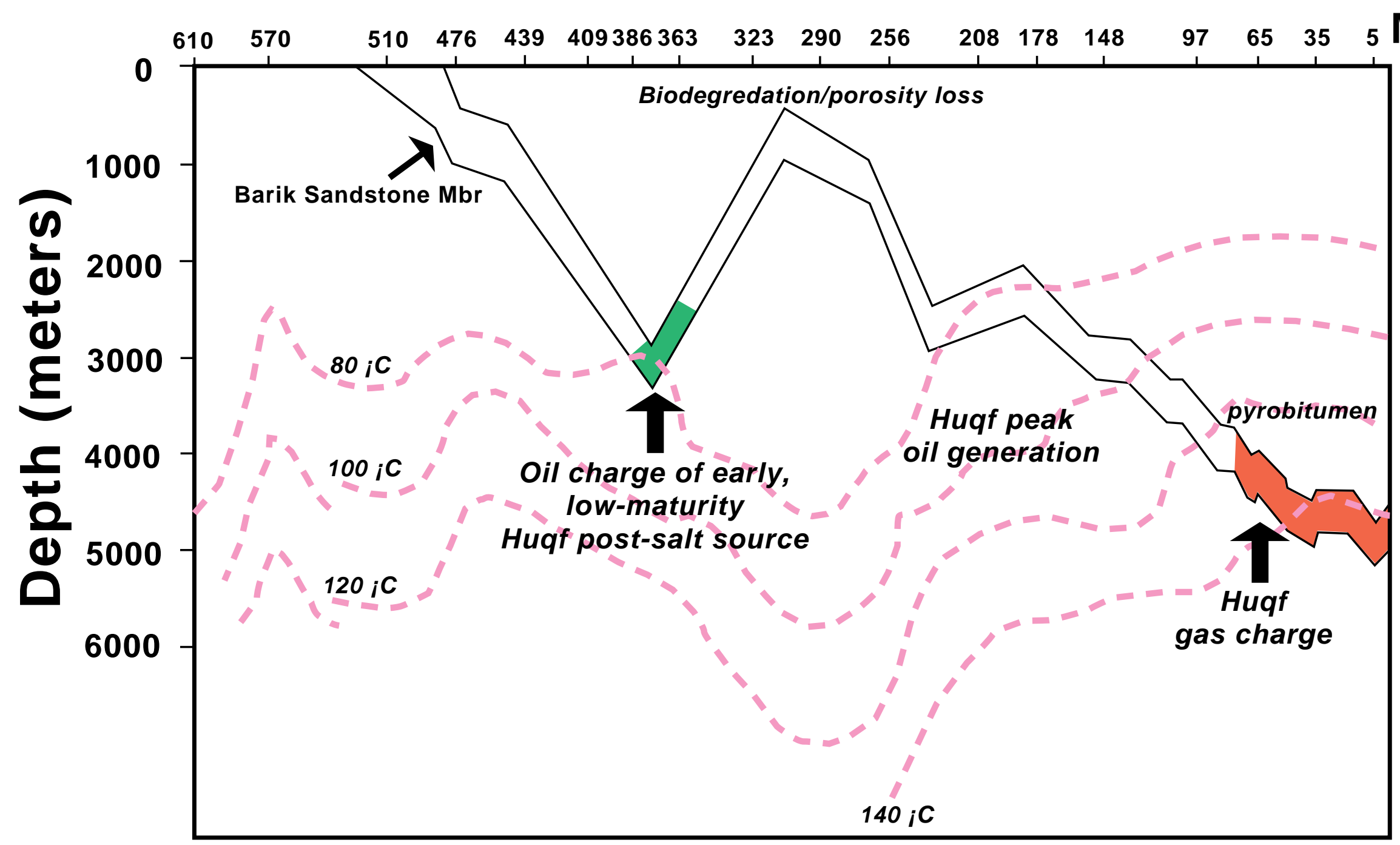

Modified from Borgomano and others (1996) 
Figure 17. -- Fahud Salt Basin Province [2016]

Natih Total Petroleum System [201602]

Natih-Fiqa Structural/Stratigraphic Assessment Unit [20160201]

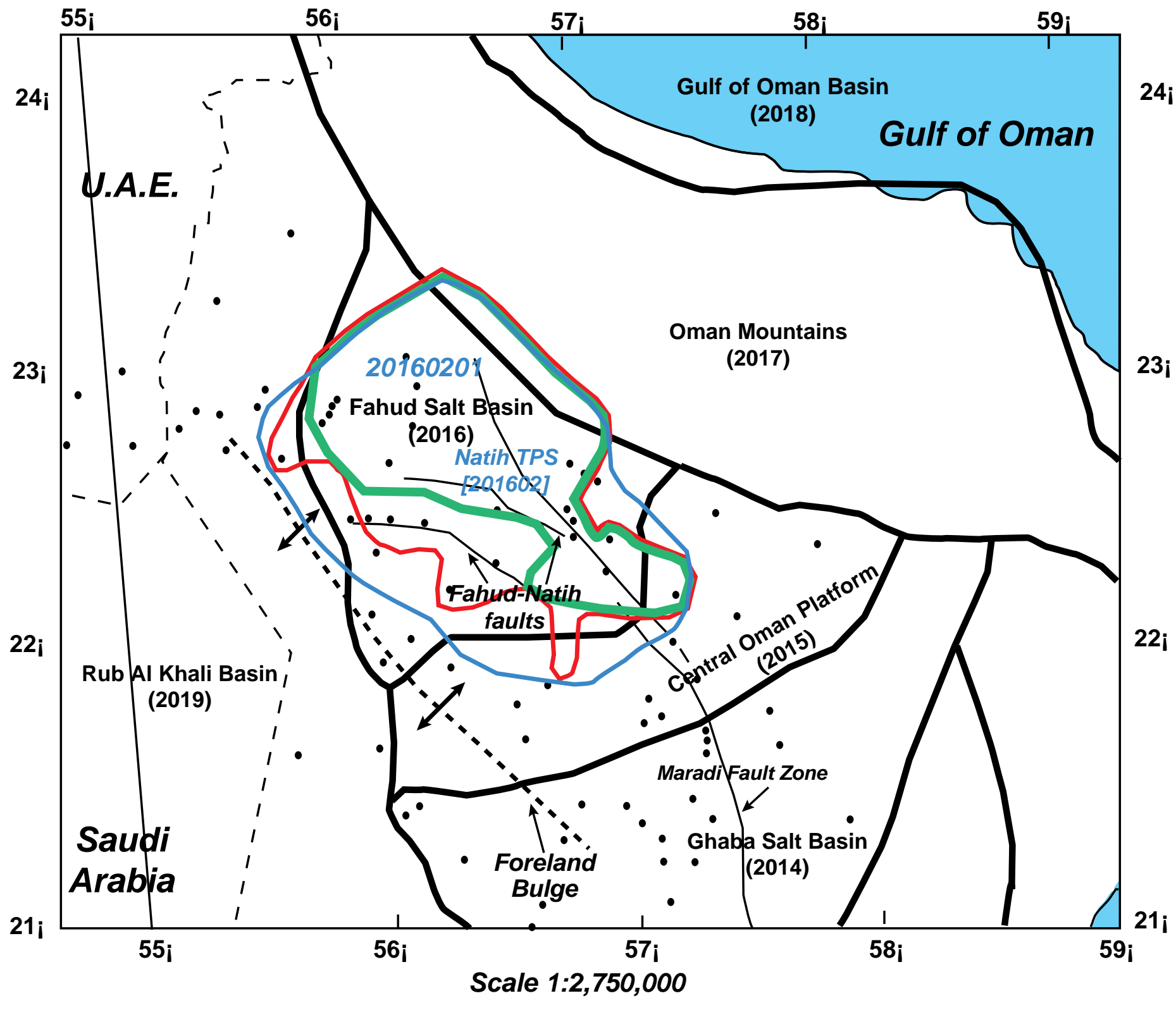

\section{Explanation}

USGS Province boundary

- Oil or Gas field centerpoint

(2016) USGS province number
Minimum Petroleum System boundary

[201602] USGS TPS number
Pod of active _ _ Country source rock boundary - boundary 20160201 USGS assessment unit number 
Figure 18.

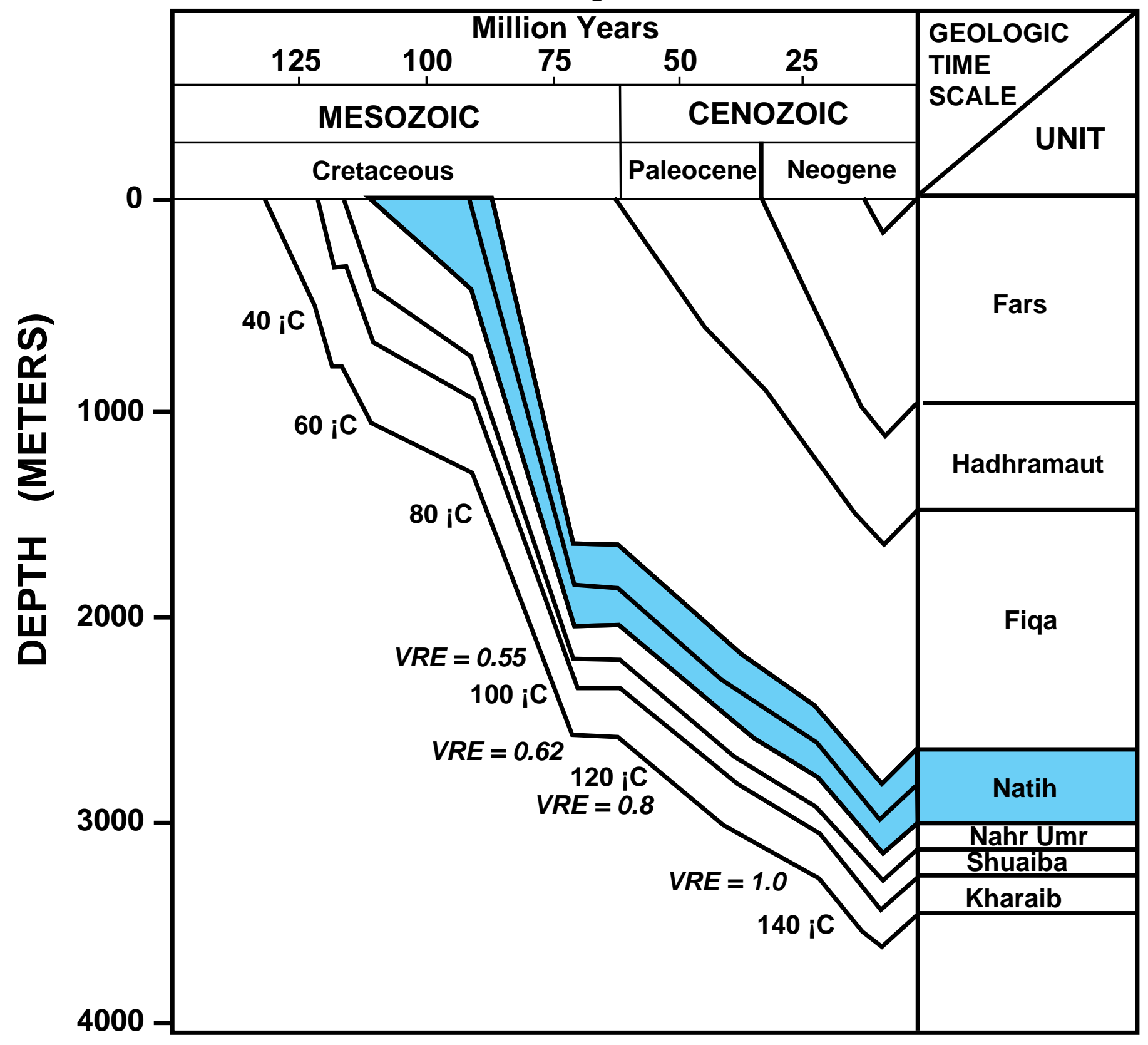


Figure 19.

\section{Burial History -- Wasia Group near Anaima-1 well, Fahud Salt Basin}

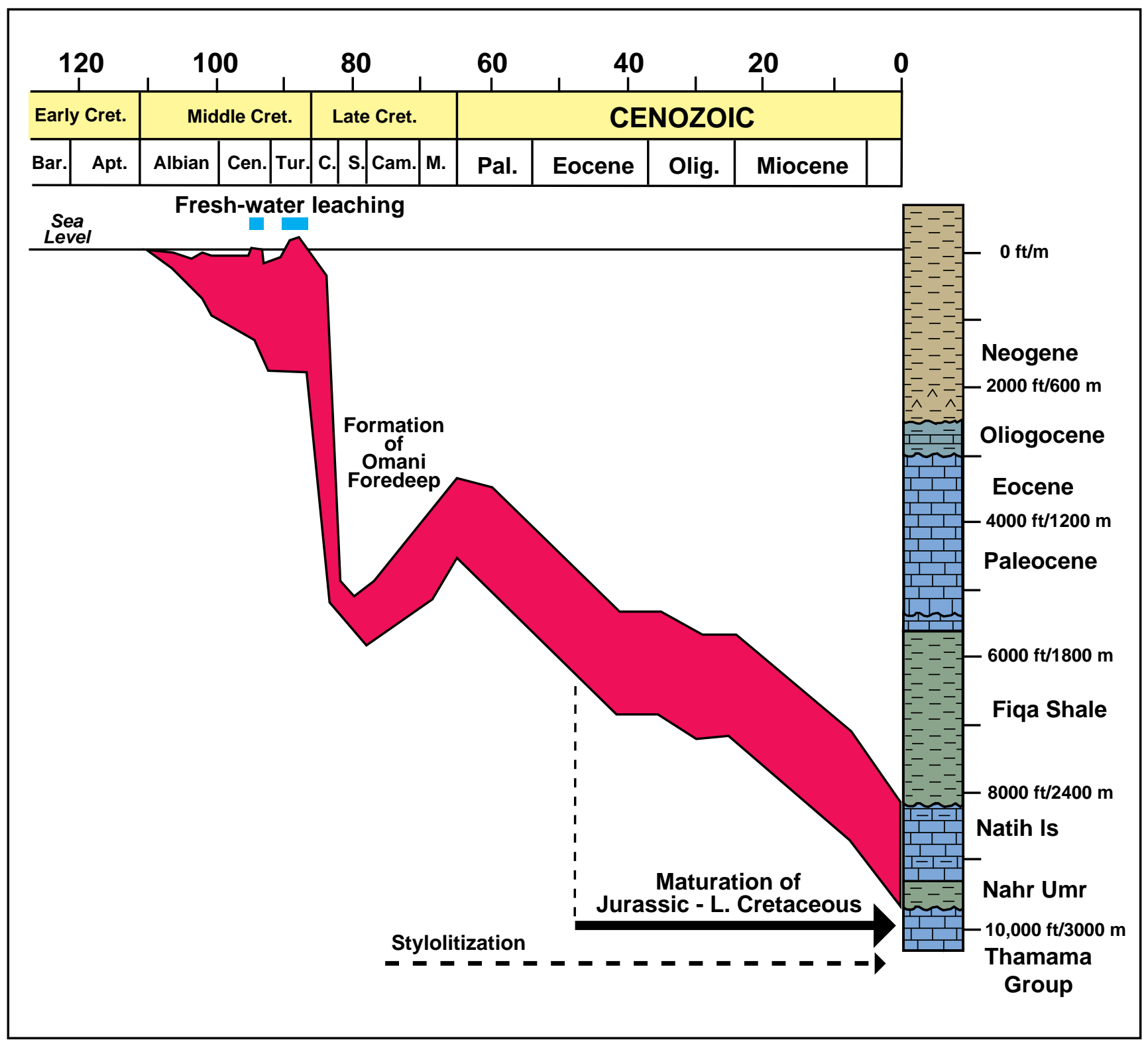

Modified from Harris and Frost (1984) 